2

\title{
Advanced analysis of nutraceuticals
}

\author{
J. Bernal, J.A. Mendiola, E. Ibáñez, A. Cifuentes* \\ Laboratory of Foodomics, Institute of Food Science Research (CSIC) \\ Nicolas Cabrera 9, Campus de Cantoblanco, 28049 Madrid, Spain
}

\section{ABSTRACT}

In this article, we present a review work on different nutraceuticals found in natural matrices together with the analytical techniques used to identify and/or quantify them with special emphasis in the period January 2005-May 2010. The work is distributed according to the different families of nutraceuticals (lipids, vitamins, proteins, glycosides, phenolic compounds, etc) discussing the analytical techniques employed for their determination (separation, spectroscopic, hyphenated techniques, etc). Information about the claimed health promoting effects of the different families of nutraceuticals is also provided together with data on the natural matrices in which they can be found (e.g., fruits, vegetables, plants, microalgae, cereals, milk, etc).

Keywords: Nutraceuticals /advanced analytical techniques / health promoting compounds / bioactive ingredients / functional foods.

*Corresponding author:

Tel\# 34-91-5618806; Fax\# 34-91-5644853; a.cifuentes@ csic.es 


\section{List of abbreviations used}

APCI: Atmospheric Pressure Chemical Ionization

CE: Capillary Electrophoresis

CID: Collision Induced Dissociation

CLA: Conjugated Linoleic Acids

CZE: Capillary Zone Electrophoresis

DAD: Diode Array Detector

ECD: Electronic Capture Detector

ELSD: Evaporative Light Scattering Detector

ESI: Electrospray Ionization

ESR: Electron Spin Resonance

FAME: fatty acid methyl esters

FASE: fatty acid steryl esters

FID: Flame Ionization Detector

FLD: Fluorescence Detector

FTIR: Fourier Transformed Infrared Spectroscopy

GC: Gas Chromatography

GPC: Gel Permeation Chromatography

HPAEC: High-Performance Anion Exchange Chromatography

HPLC: High Performance Liquid Chromatography

HPSEC: High-Performance Size-Exclusion Chromatography

HPTLC: High Performance Thin Layer Chromatography

HSCCC: High-Speed Countercurrent Chromatography

ICP: Inductively Coupled Plasma

IT: Ion Trap

LCxLC: Bidimensional Liquid Chromatography

LIF: Laser Induced Fluorescence

MAE: Microwave Assisted Extraction

MALDI: Matrix Assisted Laser Desorption Ionization

MEKC: Micella Electrokinetic Chromatography

MS/MS: Tandem Mass Spectrometry

MS: Mass Spectrometry

NMR: Nuclear Magnetic Resonance

PAD: Pulsed Amperometric Detection

PAGE: Polyacrylamide Gel Electrophoresis

PDA: Photo Diode Array

PLE: Pressurized Liquid Extraction

PMF: Polymethoxylated Flavones

prep-HPLC: Preparative High Performance Liquid Chromatography

PUFA: polyunsaturated fatty acids

QQQ: Triple Quadrupole

QTOF: Quadrupole-Time of Flight

RP: Reversed-Phase

RT-PCR: Real Time Polymerase Chain Reaction

SAX-LC: Strong Anion-Exchange Liquid Chromatography

SDS: Sodium Dodecyl Sulfate

TLC: Thin Layer Chromatography

TOF: Time of Flight

UV: Ultraviolet Detector

VWD: Variable Wavelenght Detector 


\section{INTRODUCTION}

80

81 For a long time, natural products obtained mainly from plants have been used as a prominent source of prophylactic agents for the prevention and treatment of diseases in humans and animals [1]. Hippocrates (460-370 BC) stated "Let food be your medicine and medicine be your food". Nowadays, the relationship between food and drugs is getting closer. Thus, the term nutraceutical was firstly mentioned 20 years ago to describe a union between nutrition and pharmaceutics, both key contributors to human wellnes[2]. In the last 20 years, many research publications were devoted to so-called "functional foods" and "nutraceuticals". Research into functional ingredients was showing promising prospects for the use of such ingredients in food products, thereby creating added value for manufacturers and benefits for consumer health [3]. The rising interest in this field can be seen in Figure 1 in which the exponential growing of reasearch papers dealing with nutraceuticals and functional foods in the last 20 years is shown. It is also interesting to mention that more than 150 revision works related to nutraceuticals and functional foods have been published in the same period of time. Some of them are focussed onto the beneficial properties of a particular natural matrix as sesame [4], tea [5] or spices [6], other manuscripts paid their attention onto specific natural compounds like phytochemicals [7], proteins and peptides [8] or lipids [9], meanwhile other works showed the benefits of nutraceuticals against several diseases like atherosclerosis [10] and degenerative joint diseases [11]. It must be pointed out that, to our knowledge, there is not a revision work in which the advanced analytical techniques used to analyze nutraceuticals are summarized and discussed.

Nutraceuticals as defined by Zeisel [12] are dietary supplements that deliver a concentrated form of a presumed bioactive agent from a food, presented in a non-food matrix, and used with the purpose of enhancing health in dosages that exceed those that could be obtained from normal foods. No specific regulation exists in Europe to control nutraceuticals, although they are considered under the same laws that regulate medicine and drug. In the USA, the Food and Drug Administration regulates dietary supplements under a different set of guidelines than those covering conventional foods and drug products [13].

110 Otherwise, functional foods are those that when consumed regularly produce a specific 111 beneficial health effect beyond their nutritional properties. The boundary between 112 nutraceuticals and functional foods is not always clear being the main difference the format in 
113 which they are consumed: nutraceuticals are consumed as capsules, pills, tablets, etc. while 114 functional foods are always consumed as ordinary foods. Thus, when a phytochemical is 115 included in a food formulation is considered a functional food. If the same phytochemical is included in a capsule it will constitute a nutraceutical [13].

The capacity of some plant-derived foods to reduce the risk of chronic diseases has been associated, at least in part, to the occurrence of secondary metabolites (phytochemicals) that have been shown to exert a wide range of biological activities. In general, these metabolites have low potency as bioactive compounds when compared to pharmaceutical drugs, but since they are ingested regularly and in significant amounts as part of the diet, they may have a noticeable long-term physiological effect [13]. There are numerous biological mechanisms by which nutraceuticals might be expected to exert favourable influences on pathophysiological processes. These products are safe and well tolerated, but interpretation of the collective results is hampered by heterogeneity of the studies, inconsistent results, and/or not well designed investigations. On the other hand, nutraceuticals are expected to be substantially safer and with less secondary effects than many drugs routinely prescribed in the treatment of certain symptoms; however, they are often expensive, lack pharmaceutical-level manufacturing standard controls, and may not work [14].

An additional problem related to the production and consume of nutraceuticals is that the composition and contents of active constituents in natural plants (like in any other natural source) vary depending on season, climate, temperature, humidity, soil and several other factors. So the collection, identification and maintenance of uniform quality, quantification and standardization are critical factors to consider.

The development of advanced analytical techniques is, therefore, indispensable in nutraceuticals research. It includes the identification of new nutraceuticals, characterization of their chemical structure and bioactivity, quantification in the natural source, product development, quality control in their dosage forms, etc. Due to the complexity of these natural matrices, the use of advanced analytical techniques (such as MS, NMR, HPLC, GC, CE, HPLC-

143 NMR, HPLC-MS, GC-MS and CE-MS) is mandatory in order to carry out the mentioned

144 studies. Some of these techniques are already applied for quality control of the natural product 145 confirming their composition from lot to lot and assuring the safety of the final product. Also, 146 these techniques are typically used in a combined way for product development at the initial 
stages of their discovery, mainly for facing the challenge to analyse multiple components or multiple classes of components. Moreover, the choice of the analytical technique depends also on the target compounds and the matrix in which they can be found. For example, their physico-chemical properties (polarity, size, volatility,...) will have a strong influence onto the sample preparation procedure, separation mechanism and technique (GC, HPLC, CE) and the type of detector to be employed (UV, FLD, FID, MS, etc). Moreover, advanced analytical techniques are also needed to obtain a better understanding of the health promoting effects of the nutraceuticals, and for knowing the body exposure and bioavailability after the intake of these compounds $[15,16]$. Important aspects during product development should include nutraceuticals bioactivity and bioavailability studies, so, in vitro, in vivo and clinical trials should ideally be employed. However, the current legislation on these compounds is in many countries not as demanding as for standard drugs, what usually results in minimum studies to confirm their activity.

Considering all these aspects, the aim of the present work is to present and discuss the main analytical techniques used to identify, characterize and/or quantify nutraceuticals found in different natural matrices with special emphasis in the period January 2005-May 2010. The review work is distributed according to the different families of bioactive compounds (lipids, vitamins, proteins, glycosides, phenolic compounds, etc) discussing also for each family their claimed beneficial health effect.

\section{LIPIDS}

Lipids are a large group of natural compounds which includes fats, waxes, sterols, fat-soluble vitamins (such as vitamins $\mathrm{A}, \mathrm{D}, \mathrm{E}$ and $\mathrm{K}$ ), monoglycerides, diglycerides, phospholipids, carotenoids and others. Molecules such as fatty acids and their derivatives (including tri-, di-, and monoglycerides and phospholipids), sterol-containing metabolites, such as cholesterol, are also grouped as lipids. The main biological functions of lipids include energy storage, structural components of cell membranes, and important signaling molecules. Although humans and other mammals use various biosynthetic pathways to both break down and synthesize lipids, some essential lipids cannot be made this way and must be obtained from diet. Interestingly, many papers have discussed the health benefits that can be derived from some of these lipids (see Table 1, 2 and 3). 
181 Lipids with potential benefits for human health have been identified in several natural sources

182 (cereals, fruits, animals, oils, plants, mushrooms...) using for their chemical identification gas 183 chromatography (GC) coupled to several detectors (FID, ECD, MS...), high performance 184 liquid chromatography (HPLC) with different detection modes (UV, PDA, MS, MS/MS...) or nuclear magnetic resonance (NMR) and mass spectrometry (MS) as stand-alone techniques.

The most important lipids that can be used as nutraceuticals are described below within their specific lipid group, including their potential health benefits and the advanced analytical tools employed for their determination.

\subsection{Fatty acids}

192 Fatty acids are carboxylic acids with a variable unbranched aliphatic tail (chain), which is 193 either saturated or unsaturated. They are important as nutritional substances in living 194 organisms. Long- chain polyunsaturated fatty acids (PUFA), especially those of the $\omega-3$ series, such as $\alpha$-linolenic (18:3 n-3), are essential for human metabolism and have many beneficial effects including the prevention of a number of diseases, such as coronary heart diseases, inflammation, autoimmune disorders, hypertension, hypotriglyceridemic effect, etc. $[83,84]$. Regarding to the analytical techniques more used for determining fatty acids, $95 \%$ of the works summarized in Table 1 employed gas chromatography or high temperature gas chromatography (HT-GC) with FID or MS detectors. It must be taken into account that most of the times, before GC analysis, it is necessary to prepare non-reactive derivatives of fatty acids (methyl esters, FAMEs, steryl esters FASEs, or other derivatives) which are also more volatile than the free acid components. There are only few works in which other analytical techniques have been used. As an example, Herrero et al. [51] characterized several free fatty acids in Spirulina platensis by using LC-QTOF-MS, while Yin et al. [56] used electron spin resonance (ESR) and spin-label oximetry methods to determine conjugated linoleic acids (CLAs) in soybean and other matrices [56].

Approximately in $40 \%$ of the articles devoted to the analysis of fatty acids the matrix was oil (vegetable or animal) [17-32], and all of them employed gas chromatography with FID or MS detectors. The analysis by GC-FID of fatty acids in rice oil have been carried out in several works [27-32], discussing the importance of, this matrix as source of fatty acids. 
214 Fatty acids have also been determined by GC-FID and GC-MS in salmon, catfish or 215 crustaceans [19, 27-35], beef [36], cheese [37] and plants [38, 39]. Fatty acids could also be 216 found in several fruits by using GC-FID [52-56] and in daily dietary intakes [85]. The nutritional and biological properties of mushrooms have also been studied [40-42], identifying several fatty acids that were analyzed by GC-FID previous methylation of these compounds.

According to the published literature in the reviewed period (2005-2010), an important source of fatty acids are algae (see Table 1). Fatty acids, mainly as methyl or ethyl esters, were determined by GC-MS and GC-FID in several varieties of alga (e.g., Chaetoceros Muelleri, Chlorella vulgaris, Spirulina platensis, etc.) [43-51]. Liquid chromatography coupled to a MS detector has also been employed in the analysis of fatty acid in algae [51]. The separation provided by HPLC combined with the high mass accuracy and MS/MS capability of the QTOF mass analyzer made possible the direct identification of four free fatty acids and nine polar lipids (Glycerolipids) in this complex matrix without any further sample pre-treatment or derivatization, as it could be seen in Figure 2.

\subsection{Sterols}

Sterols are an important group of organic molecules that can be found in plants, animals, and fungi, being cholesterol the most popular animal sterol. Sterols from plants, which are known as phytosterols, have been shown in clinical trials to block cholesterol absorption sites in the human intestine, and decrease the level of plasma cholesterol associated with low density lipoproteins (LDL), thus helping to reduce cholesterol in humans. According to some studies they have anti-cancer anti-inflammatory and antithrombotic activities. For these reasons, its use has been approved by US-FDA as food additive. After checking the published literature (see Table 2), it could be stated that sterols compounds have been usually identified using GC coupled to FID or MS [17, 18, 23, 24, 27, 35, 52, 57-63]. Analysis of sterols has been carried out in several classes of vegetable oils, like: olive [57], sunflower [58], Indian rice bran [27] and other plants [17, 18, 23, 24, 59]. Sterols could be also found in enriched milk and yoghurt by using an optimized GC-MS method [62], meanwhile total, free and esterified phytosterols in tetraploid and hexaploid wheats where determined by GC-FID and GC-MS [63]. GC was also employed in the analysis of the lipid composition of Italian walnut [52] and for the chemical characterisation of lipids from crustacean which can be employed for the skin-care, with potential benefits on burns, inflammations etc. [35]. Sterols have been also analyzed in different varieties of rice together 
with $\gamma$-oryzanol and other compounds like steryl ferrulates or squalene, showing antioxidant activity and decreasing cholesterol $[32,60,61]$. Chromatographic techniques as GC or HPLC have been used to determine the sterol composition in the different rice samples. Also, on-line coupling between LC and GC (on-line LC-GC-FID) can be used to determine sterols [60]. This coupling is an efficient approach for the analysis of minor constituents in complex matrices, because it avoids laborious off-line purification steps. In that work [60], $\gamma$-oryzanol is pre-separated by normal phase HPLC from other rice lipids (Figure 3a) and transferred online to GC analysis to separate its major constituents, (Figure 3b). Total $\gamma$-oryzanol content was quantified by HPLC-UV and the ratios of each individual steryl ferulate calculated by GC-FID.

\subsection{Terpenes}

260 Terpenes, which could be also named as isoprenoids, constitute the largest and most diverse class of natural products. A majority of these compounds are found only in plants, but some of the larger and more complex terpenes occur in animals. Squalene, which is a natural complex terpene produced by all plants and animals, has been proposed to be an important ingredient of the Mediterranean diet as it may be a chemopreventive substance that protects against cancer. Squalene has been analyzed in rice by GC coupled to FID and MS detectors [61]. This compound has also been identified in vegetable oils using HPLC with evaporative light scattering detection (ELSD) [64]. Terpenes and terpenoids are the primary constituents of the essential oils of many types of plants and flowers [65-67] or cereals [68] and they have shown antibacterial and antioxidant activity among other beneficial effects for human health. They have been usually analyzed by GC-MS or HPLC-UV-MS although sometimes to elucidate the real structure of these compounds NMR is preferred [68].

\subsection{Glycerolipids}

274 Glycerolipids are mainly composed of mono-, di- and tri-substituted glycerols, the most well275 known being the fatty acid esters of glycerol (triacylglycerols), also known as triglycerides. 276 These compounds posses several functional activities like antimicrobial, antiinflammatory 277 and are beneficial for the skin care [69]. There is not a unique analytical tool to analyze glycerolipids. For example, GC-FID has been used to determine these compounds in seed oils [22, 25], while silver ion thin layer chromatography (TLC) and HPLC were employed for the analysis of triacylglycerols in rice bran oil [27]. GC-MS and HPLC-MS have been also employed to identify the milk lipids that possess antimicrobial or antiinflammatory properties 
282 [69], and LC-MS was used to characterize triacylglycerols in black currant seed oil [18].

283 HPLC-ELSD has been used to identify those compounds in Chaetoceros muelleri microalgae 284 [47], and LC-QTOF-MS has been used to determine substituted glycerols in Spirulina 285 platensis microalgae [51].

\subsection{Sphingolipids}

Gangliosides are molecules composed of a glycosphingolipid with one or more sialic acids linked on the sugar chain. A glycosphingolipid is composed of an oligosaccharide plus a ceramide, the latter composed of sphingosine and a fatty acid. Gangliosides have protective action against enteric pathogens, prebiotic functions and are considered to present some therapeutic effect against neurodegenerative disorders [71]. These compounds have been determined in biological samples, including milk using several techniques. Thus, high performance thin layer chromatography (HPTLC), GC-MS, LC-MS and matrix assisted laser desorption ionisation time of flight MS (MALDI-TOF-MS) have been used to analyse gangliosides as discussed in a recent review work on this topic [70]. In that work [63], it was stated as a conclusion that MALDI-TOF is the technique of choice, due to its specificity, greater sensitivity and capacity to generate structural information.

\subsection{Carotenoids}

Carotenoids are a class of more than 600 naturally occurring pigments synthesized by plants, algae, yeast, fungi and photosynthetic bacteria. They are prominent for their distribution, structural diversity and various functions. Fruits and vegetables provide most of the carotenoids in the human diet. Carotenoids can be broadly classified into two classes, carotenes ( $\alpha$-carotene, $\beta$-carotene or lycopene) and xanthophylls ( $\beta$-cryptoxanthin, lutein or zeaxanthin). These compounds show antioxidant and inmunomodulation activities, and they can prevent degenerative diseases, such as cardiovascular diseases, diabetes, and several types

HPLC with DAD or UV detectors is the analytical technique of choice for determining carotenoids, as it can be deduced from Table 3 [43, 72-82]. Nevertheless, comprehensive liquid chromatography coupled to photodiode array and mass spectrometry detection (LCxLC-DAD-MS) have been also shown to provide impressive results in carotenoid analysis $[65,66]$. Free carotenoids and carotenoid esters from mandarin and orange juice have been identified with this methodology $[72,73]$. Some carotenoids, like $\beta$-carotene, and lycopene, 
which presents antioxidant, inmunomodulation and anti-cancer properties have been determined by HPLC-UV/Vis or DAD in Thai fruits [74], chesnut [75] and tea seed oils [76].

Algae and microalgae are also an important sources of carotenoids as astaxanthin, $\beta$-carotene, lutein, cantaxanthin, violaxanthin, lutein and neoxanthin, being HPLC the analytical tool most frequently employed to identify these compounds [43, 77-79]. In some cases, a strongly hydrophobic column (C30) has been used to separate and quantify certain carotenoids isomers from microalgae $[78,79]$.

Lycopene, a bright red carotene and carotenoid pigment, and $\beta$-carotene have been also identified in different tomato products and wastes by using HPLC, NMR or MS [80, 81] but other more easy techniques like HPTLC could be used for the lycopene determination in nutritional supplements [82].

\section{VITAMINS}

Vitamins are a diverse group of organic compounds essential in trace amounts for the normal growth and maintenance of life. To ensure the adequate intake of vitamins the human diet can be completed with a high range of multivitamin tablets and food products enriched with vitamins, in other words, these compunds are usually administered as nutraceutical or functional ingredient.

They are classified as either water-soluble or fat soluble. In humans there are 13 vitamins: 4 fat-soluble (A, D, E and K) and 9 water-soluble (8 B vitamins and vitamin C)

These compounds have diverse biochemical roles. Some have hormone-like functions as regulators of mineral metabolism (e.g. vitamin D), or regulators of cell and tissue growth and differentiation (e.g. some forms of vitamin A). Others work as antioxidants (e.g. vitamin E and sometimes vitamins B and C). The largest numbers of vitamins (e.g. $\mathrm{B}_{\text {complex }}$ vitamins) work as precursors of enzyme cofactors. Recently, it has been published one work where vitamins have been usually determined by HPLC with several detectors as UV/Vis, VWD, PDA, FLD, MS... (Table 4) although GC-FID [18, 52] and HPTLC [86] have been also employed. 
Some compounds related to vitamin B group have been identified in mushrooms by HPLCDAD-FLD [91], in more complex food matrices by using HPLC-MS/MS [92] and in energy drinks employing HPTLC [86].

Vitamin C (L-ascorbic acid or L-ascorbate) is an essential nutrient for humans and other animal species. Deficiency in this vitamin causes the disease known as scurvy in humans. This compound is also widely used as a food additive because of its antioxidant activity. In all the works summarized in Table 4 devoted to the analysis of vitamin $C$ in vegetables [95] and fruits [93, 94, 98], HPLC with UV or VWD was employed to analyse this vitamin. This approach was also used by Kim et al. [96] to determine S-methyl-L-methionine (SMM, socalled vitamin $U$ ) that may be effective in reducing ulcers of the skin and intestinal tract.

Compared to the other vitamins, the number of works about Vitamin E is by far the highest one, as it can be seen in Table 4. Vitamin E is a generic term for tocopherols and tocotrienols, and it is a fat-soluble antioxidant that block the production of reactive oxygen species formed when lipids undergoes oxidation. The most frequently employed analytical tool for determining vitamin $\mathrm{E}$ has also been HPLC coupled to all possible types of detectors as FLD, UV,PDA, VWD, MS...(Table 4). However, in two works [18, 52], based on the relative volatility and thermal stability of vitamin E, GC-FID was employed to detect vitamin E in vegetable and fruit matrix. As can be seen in Table 4, some algae can also be good natural sources of this vitamin as reported in several works in which HPLC with FLD or DAD was used to identify vitamin $\mathrm{E}[44,49,90]$. However, it has to be noted that the main natural source of vitamin E are vegetable and vegetable oils, being HPLC the analytical tool more usually employed (see Table 4).

A new HPLC-DAD method was recently developed for the simultaneous detection and quantification of water- and fat-soluble vitamins in different beverages from different natural sources (orange, strawberry, apple, peach pineapple, plum and blackcurrant juices, soybean milk and beers) [97], with the additional advantage that it was not required any previous sample preparation prior to their analysis. This fact was attributed to the use of an endcapped column, which posses an ultralow silanol activity.

\section{PROTEINS, PEPTIDES AND AMINOACIDS}


According to the information showed in Table 5, there are several benefits for the human

385 health that can de derived from the consume of some proteins, peptides and/or aminoacids. 386 They can have antibacterial, antioxidant, immunostimulating, antithrombotic and anti387 inflammatory activities; they could be used for prevention and treatment of hypertension, 388 diabetes and hepatitis among other positive effects in the organism. All these health 389 promoting effects make these compounds of great relevance as nutraceuticals.

391 Proteins, peptides and/or aminoacids are found in a great variety of matrices including 392 animals, fungi, vegetables, cereals, etc., Their identification requires the use of advanced analytical techniques due to the complexity of these compounds. As a result, HPLC, GC, CE, NMR, FTIR, ICP-MS, inmunosensors, etc, have been used to analyze these compounds. Thus, amino acids have been identified and quantified in different natural matrices using MEKC, micro chip electrophoresis or HPLC [95, 103-105].

Marine animals like sardinelle [107], tuna [108, 110], and echiuroid worms [109] are important sources of peptides with antioxidant, anticoagulant and antihypertensive properties. For their identification HPLC coupled to mass spectrometry (QQQ, QTOFMS) have been usually employed. Amino acids and protein hydrolisates have been analyzed in fishes, as herring [106], using gel permeation chromatography (GPC) and HPLC-FLD.

Another important source of proteins, peptides and amino acids is milk and dairy products. An omics-rooted study of milk proteins has been carried out using advanced analytical techniques (HPLC-MS/MS, 2D-PAGE, MALDI-TOFMS) showing the great potential of this modern approach [69]. Analysis of these compounds in milk usually is carried out employing liquid chromatography coupled to mass spectrometry, although other analytical techniques like capillary electrophoresis [99-102] have also been used for this purpose. Also, immunosensors have been applied for the determination of lactoferrin and immunoglobulin $\mathrm{G}$ 411 in milk [99].

413 Polyacrylamide gel electrophoresis (PAGE), sodium dodecyl sulfate PAGE (SDS-PAGE) and 414 2D-PAGE have been employed to analyze proteins in several matrices like milk, chick, curry 415 leaves, garlic or fungi [69, 111-114]. These more classical techniques do not provide an 416 identification of these biomolecules as accurate as CE or HPLC coupled to mass 417 spectrometry. Thus, mass spectrometry alone or coupled to HPLC has been used to 
characterize, identify and analyse proteins, peptides and amino acids in several matrices, for example lisozyme derived peptides with antimicrobial activity were detected in hen eggs [115], while several cyclopeptides with estrogen activity in vivo were found in cow cockle seeds [116].

High-performance anion exchange chromatography coupled with pulsed amperometric detection (HPAEC-PAD) has been used to measure the $\alpha$-amylase inhibitor activity of phaseolamin from kidney bean [117]. Using several advanced analytical techniques, as ICPMS, MALDI-TOF-MS, nano-HPLC-MS/MS it was possible to obtain the whole selenopeptide map of Brazilian nuts [118]. As an example, Figure 4 shows a size exclusion ICP-MS chromatogram of the extracted proteins of Brazilian nuts together with the MALDITOF spectrum of one protein fraction [118].

\section{CARBOHYDRATES, GLYCOSIDES AND RELATED COMPOUNDS}

Carbohydrates perform numerous essential roles in living beings. Thus, monosaccharides are the major source of energy for metabolism, while polysaccharides serve for the storage of energy and can act as structural components. Moreover, other beneficial health effects have been linked to these compounds, including their prebiotic effect or other less common as antioxidant or antiinflammatory activity. The identification and quantification of these compounds have brought about the development of multiple analytical trategies mainly based on analytical techniques such as HPLC, GC, CE and/or NMR [68, 116, 119-132].

Chondritin sulphate is a mucopolysaccharide, or sulfated glycosaminoglycan, that acts as an important structural component of cartilage providing much of its resistance to compression. Along with glucosamine, chondroitin sulfate has become a widely used dietary supplement for treatment of osteoarthritis. It has been determined in raw materials and formulations by CE-UV [119]. It has also been analysed in dietary supplements by using a specific and sensitive agarose-gel electrophoresis and strong-anion exchange-high performance liquid chromatography method [120], and this latter technique was followed by a high-performance size-exclusion chromatography (HPSEC) to determine the chondritin sulphate molecular mass [121]. 
Other saccharides have been analysed in different matrices (plant, fungus, etc) with different analytical techniques like NMR, HPLC or CE [122-124]. Two different CE approaches have been developed to determine glucosamine, an important and abundant monosacharide, in nutraceutical preparations $[125,126]$. This compound is shown to be effective in treating osteoarthritis pain, rehabilitating cartilage, renewing synovial fluid and repairing joints that have been damaged by osteoarthritis.

Glycosides are compounds containing a carbohydrate molecule (sugar) bound to a noncarbohydrate moiety. These compounds are mainly found in plants, and they can be converted, by hydrolytic cleavage, into a sugar and a non-sugar component (aglycone). They are named specifically by the type of sugar that they containe, as glucosides (glucose), pentosides (pentose), fructosides (fructose), etc. Many plant glycosides have shown activity for cancer prevention, as well as antidiabetic, anti-obese, antibacterial or antineoplastic effect [127-130]. Among the multiple glycosides, several complex glucosides have been determined in plants and cereals using HPLC, MS, NMR or GC as can be seen in Table 6.

Saponins, which are amphipathic glycosides, have been also studied in seeds, plants and cereals. Saponins can stimulate muscle growth and raise testosterone levels [131] and they can also show antibacterial, immunological and antidiabetic properties $[68,116,132]$. The analytical methods used to determine saponins have been GC-MS [131] as well as HPLC, NMR, and MS [68, 116, 132].

\section{PHENOLIC COMPOUNDS}

Under the denomination "phenolic compounds" there are more than 4000 compounds divided in 12 subclasses. Vegetables, fruits, fungi and some bacteria produce, as part of their secondary metabolism, a wide variety of phenolic compounds. Some of them are highly important for their physiological functions, some others are used to defend themselves from stress situations or to attract or repeal other organisms. In the early 1960s, phenolic compounds were widely viewed as metabolic waste products that were stored in the plant vacuole. Whilst there was interest at that time in their function as flower colorants, and in their distribution between plant taxa, the earliest investigations of their biosynthesis had just begun [133]. In foods this kind of compounds acts as pigments, antioxidants, flavor precursors, etc $[133,134]$ and, nowadays, as part of our diet they have been associated with 
several health promoting activities such as: decreasing blood sugar levels, reducing body weight [135], anticarcinogenic [136, 137], antiinflamatory, antiaging [138] and antithrombotic activity [139, 140]. However, the major claimed activity of phenolic compounds has been as antioxidants, as can be seen in Table 7.

The main difference between bioactive phenolic compounds that can act as nutraceuticals and other phenolic compounds without noticeable bioactivity is their metabolic origin. The first ones are derived from two biosynthetic routes: shikimic acid and/or polyacetates routes. Usually phenolic compounds bind sugars or other phenolic compounds. A fast classification of phenolic compounds could be done as follows [133, 134]:

-Benzenediols: are simplest structures, based on the hidroxy phenol.

-Phenolic acids: derived from benzoic acid (C6-C1) or cinnamic acid (C6-C3), when phenolic acids are associated as long polymers form tannins and lignans.

-Coumarins: with a basic structure of 2H-1-benzopiran-2-one.

-Flavonoids: with a basic structure of diarylpropane (C6-C3-C6), this group is the widest and is formed by subfamilies like catechins, flavones, flavonols, flavanones, isoflavonoids and anthocyanes [134].

The classical method to analyze total phenolic compounds is the Folin-Ciocalteau method where the measured colour change is associated with the reduction of a molibdo-tungstate reagent induced by the phenols in the sample. Curently, HPLC has become the analytical method of choice for phenolic compounds. HPLC was first used for the determination of flavonoids in 1976 by Fisher and Wheaton [134]. Since then, many methods have been developed for the detection and quantification of phenolic compounds, being liquid chromatography the most used technique, as seen in Table 7 [23, 42, 55, 75, 76, 89, 93-95, 97 , 141-201, 218-229]. Besides HPLC, other separation techniques have been used, namely, GC [202-205], TLC [206, 207] or CE [208-211], and also spectrometric techniques [212-217].

In HPLC, reversed-phase columns (RP) are the most commonly used, mainly C18, ranging from 150 to $250 \mathrm{~mm}$ in length with ID ranging from $4.6 \mathrm{~mm}$, and particle sizes of $5 \mu \mathrm{m}$. In general terms, endcapped columns provide better separations. Elution mobile phases are usually binary, with an aqueous acidified solvent (solvent A) such as aqueous acetic acid, perchloric acid, or formic acid and an organic solvent such as methanol or acetonitrile, generally acidified (solvent B). Trifluoroacetic acid in both solvents enhances the resolution 
and eliminates peak tailing of catechins. In terms of detection systems, UV-visible with diode array detection is the standard method used for detection of phenolic compounds [134]. Simple phenolic compounds present a single absorption band in the range 240-290 nm, while, more complex phenolic compounds (flavonoids family) present a second absorption band with a maximum in the 300- to 550-nm range, induced by the B ring [133].

When MS is used the most employed ion source is ESI due to both the polarity and molecular weight of these analytes match well the requirements of this interface. For example AbadGarcía et al [157] developed an interesting method based in HPLC-DAD-ESI-MS/MS (triple quadrupole mass spectrometer) for the characterization of unknown phenolic compounds in fruit juices. Their HPLC method consisted of using a C18 column with a gradient and acetic acid-water (0.5:99.5, v/v) and methanol as eluents. Their strategy was based in four steps: (i) taking into account its UV-visible spectrum and elution order, assign the unknown polyphenol to a polyphenol class, (ii) identify the quasi-molecular ion using positive and negative MS spectra, being supported by adducts generated with solvent or sodium and molecular complexes, (iii) determinate the pattern of glycosylation in positive mode using ESI(+)-CID MS/MS product ion scan experiments, selecting the quasi-molecular ion as precursor ion, and finally, (iv) study the identity of the aglycone through ESI(+)-CID MS/MS product ion spectra from the protonated aglycone, $\left[\mathrm{Y}_{0}\right]^{+}$. In this work, a triple quadrupole mass spectrometer was used, which is more indicated for the quantification of known analytes. To overcome this limitation, Abad-García et al. studied the elution time, UV spectra and fragmentation patterns of each polyphenol before analyzing real samples. One example of the study of the fragmentation pattern can be seen in Figure 5.

The previously depicted strategy is highly useful when dealing with known compounds, but for the study of previously undescribed compounds, other kind of mass spectrometers must be used. For example, Fu et al. [160] used LC-DAD coupled to a time-of-flight mass spectrometer (ESI-TOF-MS) and an ion-trap multiple mass spectrometer (ESI-IT-MS ${ }^{\mathrm{n}}$ ) to characterize novel phenolic compounds in extra virgin olive oils.

Despite LC is the most used separation technique to analyze phenolic compounds, some authors have used CE for this purpose [208, 210, 211]. For example, Orlandini et al [210] developed by chemometric optimization a rapid and simple method based on capillary electrophoresis for the quality control of nutraceuticals (effervescent tablets) containing 
resveratrol. This compound is thought to be one of the compounds responsible for the cardioprotective action of red wine and is promoted as an antioxidant for the prevention of atherosclerosis. Resveratrol also has mixed agonist/antagonist activity at oestrogen receptors and some anti-inflammatory and antiproliferative activity [210]. In order to set up the method for the quality control of the mentioned nutraceuticals (effervescent tablets), a multivariate strategy based in response surfaces was followed. In this study, the factors considered were buffer concentration, percentage of acetonitrile and voltage. The factors were studied in the following experimental range: $X_{1}$, buffer concentration; $X_{2}$, percentage of acetonitrile; $X_{3}$, voltage. The resulting method, found by Derringer desirability function, made it possible to achieve good resolution and low analysis time $(7 \mathrm{~min})$ also in the presence of a complex sample matrix. The optimisation involved the separation of 11 effervescent tablet components detectable at $280 \mathrm{~nm}$, including the active compounds vitamin $\mathrm{C}$, vitamin $\mathrm{B}_{2}$, flavanones and hydroxycinnamic acids [210].

In terms of detectors, UV and MS are the dominant, but for certain purposes FTIR and NMR have been used [179, 181, 183, 197, 199, 200, 212-217, 223, 224]. A good example of the use of FTIR for the analysis of nutraceutical compounds was done by Manthey in 2006 [214], he analyzed polymethoxylated flavones (PMF) in orange peel oil, which are by-products of juice industry. Polymethoxylated flavones exhibit anticancer and antiinflammation actions, as well as triglyceride and low-density lipoprotein cholesterol-lowering properties. Although this analysis (FTIR) does not provide information on the levels of individual PMFs, it provides a rapid, solvent-free measurement of the total PMF content in orange oil residues. The ethanol extraction of the PMFs from the bulk of the oil residue provides a rapid and easy enrichment and recovery of the PMF from the oil residues. LH20 size exclusion chromatography provides a means of isolating high percentage PMF material, consisting of relative proportions of the individual PMFs similar to those in the original oil residues. As can be seen in Figure 6 the near absence of other non-PMF constituents is evident by the low intensity of the $v(C=O)$ vibration at $1724 \mathrm{~cm}^{-1}$. The intensities of the FTIR vibrations of the phenyl ring $v(C=C)$ stretch at $1515 \mathrm{~cm}^{-1}$ of the PMFs can be used, relative to the intensity of the carbonyl stretch at $1733 \mathrm{~cm}^{-1}$ of the non-PMF orange oil residue components, to measure PMF content. Excellent correlations for the ratios of the intensities of these vibrations and the total PMF content were observed irrespective of the source, viscosity, and presence of particulate material. 


\section{OTHER BIOACTIVE COMPOUNDS}

Sulphur rich compounds in food have shown to reduce significantly the risk of cancer development. Sulforaphane belongs to this group of compounds and it is usually found in cruciferous vegetables such as broccoli, cabbage, Brussels sprouts, etc. As can be sen in Table 8, HPLC-UV [230] and GC-MS [231] have been applied to determine sulforophane in cruciferous vegetables.

Phenylpropanoid amides are plant-specific secondary metabolites and represent an important class of nutraceuticals, having strong antioxidant and chemotherapeutic effects. They have been studied by Kang et al [232], in a work where HPLC combined with real time polymerase chain reaction (RT-PCR) have been used to quantify and analyse these compounds in transgenic tomato tissues.

600

An interesting combination of analytical techniques (all-liquid high-speed countercurrent chromatography technique and $1 \mathrm{D}$ - or 2D-NMR) has been used to characterize phaeophitins, a degradation product of chlorophylls, in leaves and stems of plants [233]. Other nutraceuticals which have been also studied by HPLC are monacolins in rice [234], capsaicinoids from peppers [235] and different acids and related compounds in plants [96, 236], whose health promoting effects are shown in Table 8.

607

\section{CONCLUSIONS AND FUTURE TRENDS}

609

610 In this work, we have presented an overview on nutraceuticals covering the period January 611 2005-May 2010, discussing the different bioactive compounds (lipids, vitamins, proteins, 612 glycosides, phenolic compounds...), their claimed health promoting effects, the analytical 613 techniques mainly employed for their analysis and the natural matrices in which they are 614 found. The scientific interest of this topic is demonstrated through the number of research 615 papers (> 200) published on this topic in the reviewed period.

617 It can be concluded that the preferred analytical tools for analysing bioactive compounds are 618 GC and HPLC, probably due to their versatility, generalized availability, low-cost and 619 simplicity. Other techniques such as CE, MS, NMR or FTIR have also given good results, 620 although their use is not as widespread as GC or HPLC. 
622 It must be pointed out that practically all the claimed health promoting effects of the bioactive

623 compounds presented in this work, have not been recognized yet by the pertinent authorities 624 (EFSA, FDA, etc), because in most of the cases there is a lack of long-term studies and/or 625 clinical trials that demonstrate unquestionably their health effects.

626

627 In this sense, it is highly required the development and application of advanced analytical 628 approaches as the new Foodomics strategy [227] in order to obtain superior information on 629 nutraceuticals. This new information should make easier the identification in natural matrices 630 of new nutraceuticals, their chemical characterization and the unquestionable confirmation of 631 their health promoting effects when combined with well designed clinical trials.

632

\section{ACKNOWLEDGEMENTS}

634

635 J.B. would like to thank MEC for his Juan de la Cierva contract. This work was supported by 636 Projects AGL2008-05108-C03-01 and CONSOLIDER INGENIO 2010 CSD2007-00063 637 FUN-C-FOOD (MEC).

638 
[1] D. Bagchi, Nutraceuticals and functional foods regulations in the United States and around the world, Toxicol., 221 (2006) 1-3.

[2] C.A. Haller, Nutraceuticals: Has There Been Any Progress?, Clin. Pharmacol. Ther., 87 (2010) 137-141.

[3] P. Coppens, M.F. Da Silva, S. Pettman, European regulations on nutraceuticals, dietary supplements and functional foods: A framework based on safety, Toxicol., 221 (2006) 59-74.

[4] P.J. Kanu, K. R. Zhu, J. B. Kanu, H. M. Zhou, H. F. Quian, K. X. Zhu, Biologically active components and nutraceuticals in sesame and related products: a review and prospect, Trends Food Sci. Tech. 18 (2007) 599-608

[5] C. J. Dufresne, E. R. Farnworth, A review of latest research findings on the health promotion properties of tea, J. Nutr. Biochem. 12 (2001) 404-421

[6] K. Srinivasan, Role of Spices Beyond Food Flavoring: Nutraceuticals with Multiple Health Effects, Food Rev. Int. 21(2) (2005) 167-188

[7] C. J. Dillard, J. B. German, Phytochemicals: nutraceuticals and human health, J. Sci. Food Agr. 80 (2000) 1744-1756

[8] E. G. De Mejia, V. P. Dia, The role of nutraceuticals proteins and peptides in apoptosis, angiogenesis and metastasis of cancer cells, Cancer Metast. Rev. 29 (2010) 511-528

[9] M. Iriti, M. Rossoni, F. Faoro, Melatonin content in grape, myth or panacea?, J. Sci. Food Agr. 86 (2006) 1432-1438

[10] L. Badimon, G. Vilahur, T. Padro, Nutraceuticals and atherosclerosis, human trials, Cardiovasc. Therap. 28 (2010) 202-215

[11] R. Googs, A. Vaughan-Thomas, P. D. Clegg, S. D, Carter, J. F. Innes, A. Mobasheri, M. Shakibaei, W. Schwab, C. A. Bondy, Nutraceutical therapies for degenerative joint diseases, a critical review, Crit. Rev. Food Sci. 45 (2005) 145-164

[12] S.H. Zeisel, Regulation of 'nutraceuticals', Science, 285 (1999) 1853-1855.

[13] J.C. Espín, M.T. García-Conesa, F.A. Tomás-Barberán, Nutraceuticals: Facts and fiction, Phytochemistry, 68 (2007) 2986-3008.

[14] T.E. McAlindon, Nutraceuticals: Do they work and when should we use them?, Clin. Rheumatol., 20 (2006) 99-115.

[15] B. Sener, L. Orhan, Discovery of drug candidates from some Turkish plants and conservation of biodiversity, Pure Appl. Chem. 77 (2005) 53-64; M. M. Rafi, Significance of Bcl-2 protein phosphorylation in cancer cells for pharmaceutical and nutraceuticals discovery, in: F. Shahidiu, C. T. Ho, S. Watanabe, T. Osawa (Eds.), Food Factors in Health Promotion and Disease Prevention, American Chemical Society, Washington, DC, 2003, pp. 72-85

[16] O. Laporta, L. Perez-Fons, K. Balan, D. Paper, V. Cartagena, V. Micol, Bifunctional antioxidative oligosaccharides with antiinflmattory activity for joint health, Agro Food Ind. Hi. Tec. 15 (2004) 30-33

[17] F. Anwar, R. Przybylski, M. Rudzinska, E. Gruczynska, J. Bain, Fatty acid, tocopherol and sterol compositions of Canadian prairie fruit seed lipids, J. Am. Oil Chem. Soc. 85 (2008) 953-959

[18] A. M. Bakowska-Barczak, A. Schieber, P. Kolodziejczyk, Characterization of Canadian black currant (Ribes nigrum L.) seed oils and residues, J. Agric. Food Chem. 57 (2009) $11528-11536$

[19] R. A. Kaskoos, S. Amin, M. Ali, S. R. Mir, Chemical composition of fixed oil of Olea europaea drupes from Iraq, Res. J. Med. Plant 3 (4) (2009) 146 -150.

[20] P.Mitra, H.S. Ramaswamy , K.S.Chang, Pumpkin (Cucurbita maxima) seed oil extraction using supercritical carbon dioxide and physicochemical properties of the oil, J. Food Eng. 95 (2009) 208-213 

types of Ethiopian mustard with high levels of polyunsaturated fatty acids, Ind. Crop. Prod. 27 (2008) 359-363 Apiaceae seed oils: Composition and regiodistribution of fatty acids, Eur. J. Lipid Sci. Technol. 111 (2009) 164-169

[23] K.L. Nyam, C.P. Tan, O.M. Lai, K. Long, Y.B. Che Man, Physicochemical properties and bioactive compounds of selected seed oils, LWT-Food Sci. Technol., 42 (2009) 13961403 .

[24] M. F. Ramadan, G. Sharanabasappa, Y.N. Seetharam, M. Seshagiri, J.-T. Moersel, Characterisation of fatty acids and bioactive compounds of kachnar (Bauhinia purpurea L.) seed oil, Food Chem. 98 (2006) 359-365 [25] W. A. Wannes, B. Mhamdi, J. Sriti, B. Marzouk, Glycerolipid and fatty acid distribution in pericarp, seed and whole fruit oils of Myrtus communis var. italica, Ind. Crop. Prod. 31 (2010) 77-83

[26] R. Zadernowski, M. Naczk, S. Czaplicki, Chemical composition of Pinus sibirica nut oils, Eur. J. Lipid Sci. Technol. 111 (2009) 698-704

[27] R. Denev, I. Kuzmanova, S. Panayotova, S. Momchilova, V. Kancheva, B. R. Lokesh, Lipid composition of Indian rice bran oil, C.R. Acad. Bulg. Sci., 62(6) (2009) 709-716

[28] C. E.C. Rodrigues, M. M. Onoyama, A. J.A. Meirelles, Optimization of the rice bran oil deacidification process by liquid-liquid extraction, J. Food Eng. 73 (2006) 370-378

[29] S. Gunawan, S. R. Vali, and Y.-H. Ju, Purification and identification of rice bran oil fatty acid steryl and wax Esters, J. Am. Oil Chem. Soc. 83 (2006) 449-456

[30] C. Balachandran, P.N. Mayamol, Shiny Thomas, Divya Sukumar, A. Sundaresan, C. Arumughan, An ecofriendly approach to process rice bran for high quality rice bran oil using supercritical carbon dioxide for nutraceutical applications, Bioresource Technol. 99 (2008) 2905-2912

[31] M. B. Reena, B. R. Lokesh, Hypolipidemic Effect of oils with balanced amounts of fatty acids obtained by blending and interesterification of coconut oil with rice bran oil or sesame oil, J. Agric. Food Chem. 55 (2007) 10461-10469

[32] R. Przybylski, D. Klensporf-Pawlik, F. Anwar, M. Rudzinska, Lipid components of North American wild rice (Zizania palustris), J. Am. Oil Chem. Soc. 86 (2009) 553-559

[33] T. Sun, Z. Xu, W. Prinyawiwatkul, FA composition of the oil extracted from farmed atlantic salmon (Salmo salar L.) viscera, J. Am. Oil Chem. Soc 83 (2006) 615-619

[34] B. B. Manning, M. H. Li, E. H. Robinson, B. C. Peterson, Enrichment of channel catfish (Ictalurus punctatus) fillets with conjugated linoleic acid and omega-3 fatty acids by dietary manipulation, Aquaculture 261 (2006) 337-342

[35] Di.L. Badiu, A.M. Balu, L.Barbes,R.Luque, R.Nita, M.Radu, E.Tanase, N. Rosoiu, Physico-chemical characterisation of lipids from Mytilus galloprovincialis (L.) and Rapana venosa and their healing properties on skin burns, Lipids 43 (2008) 829-841

[36] C. A Daley, A. Abbott, P. S. Doyle, G. A. Nader, S. Larson, A review of fatty acid profiles and antioxidant content in grass-fed and grain-fed beef, Nutr. J. 9(10) (2010) 1-12 [37] R. P. Shobha, R. Agrawal, Volatile compounds of therapeutic importance produced by Leuconostoc paramesenteroides, a native laboratory isolate, Turk. J. Biol. 31 (2007) 35-40 [38] C.-S.Lai, R.H.M.H. Mas, N.K. Nair, S.M. Mansor, V. Navaratnam, Chemical constituents and in vitro anticancer activity of Typhonium flagelliforme (Araceae), J. Ethnopharmacol. 127 (2010) 486-494

[39] R. Guimarães, R. Guimarães, L. Barros, A. M. Carvalho, M. J. Sousa, J. S. Morais, I. C.F.R. Ferreira, Aromatic plants as a source of important phytochemicals: Vitamins, sugars 
and fatty acids in Cistus ladanifer, Cupressus lusitanica and Eucalyptus gunnii leaves, Ind. 739 Crop. Prod. 30 (2009) 427-430., (2009).

740 [40] L. Barros, T. Cruz, P. Baptista, L. M. Estevinho, Isabel C.F.R. Ferreira, Wild and 741 commercial mushrooms as source of nutrients and nutraceuticals, Food Chem. Toxicol. 46 (2008) 2742-2747

[41] S. A. Heleno, L. Barros, M. J. Sousa, A. Martins, I. C.F.R. Ferreira, Study and characterization of selected nutrients in wild mushrooms from Portugal by gas chromatography and high performance liquid chromatography, Microchem. J. 93 (2009) 195 199

[42] L. Barros, B. A. Venturini, P. Baptista, L. M. Estevinho, and I. C. F. R. Ferreira, Chemical composition and biological properties of Portuguese wild mushrooms: a comprehensive study, J. Agric. Food Chem. 56 (2008) 3856-3862

[43] I. Rodríguez-Meizoso, L. Jaime, S. Santoyo, A. Cifuentes, G. García-Blairsy Reina, F. J. Señoráns, and E. Ibáñez, Pressurized Fluid Extraction of Bioactive Compounds from Phormidium Species, J. Agric. Food Chem. 56 (2008) 3517-3523

[44] Y. Durmaz, M. Monteiro, N. Bandarra, S. Gokpinar, O. Isik, The effect of low temperature on fatty acid composition and tocopherols of the red microalga, Porphyridium cruentum. J. Appl. Phycol. 19 (2007) 223-227

[45] M. Plaza, S. Santoyo, L. Jaime, G. García-Blairsy Reina, M. Herrero, F.J. Señoráns, E. Ibáñez, Screening for bioactive compounds from algae, J. Pharmaceut. Biomed. 51 (2010) 450-455

[46] M. Plaza, M. Herrero, A. Cifuentes and E. Ibáñez, Innovative natural functional ingredients from microalgae, J. Agric. Food Chem. 57 (2009) 7159-7170

[47] J. A. Mendiola, C. F. Torres, P. J. Martín-Álvarez, S. Santoyo, B. O. Arredondo, F. J. Señorans, A. Cifuentes, E. Ibáñez, Use of supercritical $\mathrm{CO}_{2}$ to obtain extracts with antimicrobial activity from Chaetoceros muelleri microalga. A correlation with their lipidic content, Eur. Food Res. Technol. 224 (2007) 505-510

[48] M. Terasaki, A. Hirose, B. Narayan, Y. Baba, C. Kawagoe, H. Yasui, N. Saga, M. Hosokawa and K.Miyashita, Evaluation of recoverable functional lipid components of several brown seaweeds (phaeophyta) from japan with special reference to fucoxanthin and fucosterol contents, J. Phycol. 45 (2009) 974-980

[49] L. Gouveia, B.P. Nobre, F.M. Marcelo, S. Mrejen, M.T. Cardoso , A.F. Palavra , R.L. Mendes, Functional food oil coloured by pigments extracted from microalgae with supercritical $\mathrm{CO}_{2}$, Food Chem. 101 (2007) 717-723

[50] M.G. Sajilata, Rekha S. Singhal, Madhusudan Y. Kamat, Supercritical $\mathrm{CO}_{2}$ extraction of g-linolenic acid (GLA) from Spirulina platensis ARM 740 using response surface methodology, J. Food Eng. 84 (2008) 321-326

[51] M. Herrero, M. J. Vicente, A. Cifuentes, E. Ibáñez, Characterization by highperformance liquid chromatography/electrospray ionization quadrupole time-of-flight mass spectrometry of the lipid fraction of Spirulina platensis pressurized ethanol extract, Rapid Commun. Mass Spectrom. 21 (2007) 1729-1738

[52] V. Verardo, A. Bendini, L. Cerretani, D. Malaguti, E. Cozzolino and M. F. Caboni, Capillary gas chromatography analysis of lipid composition and evaluation of phenolic compounds by micellar electrokinetic chromatography in Italian walnut (Juglans Regia l.): irrigation and fertilization influence, J. Food Quality 32 (2009) 262-281

[53] S. Ercisli, E. Orhan, Some physico-chemical characteristics of black mulberry (Morus nigra L.) genotypes from Northeast Anatolia region of Turkey, Sci. Hortic-Amsterdam 116 (2008) 41-46 
[54] E. Kafkas, S. Ercisli, K. N. Kemal, K. Baydar, H. Yilmaz, Chemical composition of blood orange varieties from Turkey: A comparative study, Pharmacogn. Mag. 5 (2009) 329335

[55] L. Barros, A.M. Carvalho, J.S. Morais, I.C.F.R. Ferreira, Strawberry-tree, blackthorn and rose fruits: Detailed characterisation in nutrients and phytochemicals with antioxidant properties, Food Chem., 120 (2010) 247-254. Effects of conjugated linoleic acid (CLA) isomers on oxygen diffusion-concentration products Effects of conjugated linoleic acid (CLA) isomers on oxygen diffusion-concentration products in liposomes and phospholipid solutions, J. Agric. Food Chem. 54 (2006) 7287-7293

[57] G. Sivakumar, C. B. Bati, E. Perri, N. Uccella, Gas chromatography screening of bioactive phytosterols from mono-cultivar olive oils, Food Chem. 95 (2006) 525-528

[58] L. Vázquez, C. F. Torres, T. Fornari, N. Grigelmo, F. J. Señoráns, G. Reglero, Supercritical fluid extraction of minor lipids from pretreated sunflower oil deodorizer distillates, Eur. J. Lipid Sci. Technol. 108 (2006) 659-665

[59] H. Schwartz, V. Ollilainen, V. Piironen, A.-M. Lampi, Tocopherol, tocotrienol and plant sterol contents of vegetable oils and industrial fats, J. Food Compos. Anal. 21 (2008) 152-161 [60] A. Miller, K.-H. Engel, Content of $\gamma$-Oryzanol and Composition of Steryl Ferulates in Brown Rice (Oryza sativa L.) of European Origin, J. Agric. Food Chem. 54 (2006) 81278133

[61] T.-Y. Ha, S.-N. Ko, S.-M. Lee, H.-R. Kim, S-H. Chung, S-R. Kim, H.-H. Yoon, I-H. Kim, Changes in nutraceutical lipid components of rice at different degrees of milling, Eur. J. Lipid Sci. Technol. 108 (2006) 175-181

[62] R. Santos, E. Limas, M. Sousa, M. da C. Castilho , F. Ramos, M. I. Noronha da Silveira, Optimization of analytical procedures for GC-MS determination of phytosterols and phytostanols in enriched milk and yoghurt, Food Chem. 102 (2007) 113-117

[63] G. Iafelice, V. Verardo, E. Marconi, M. F. Caboni, Characterization of total, free and esterified phytosterols in tetraploid and hexaploid wheats, J. Agric. Food Chem. 57 (2009) 2267-2273

[64] L. Vázquez, C. F. Torres, T. Fornari, F. J. Señoráns, G. Reglero, Recovery of squalene from vegetable oil sources using countercurrent supercritical carbon dioxide extraction, J. Supercrit. Fluids 40 (2007) 59-66

[65] M.-T. Golmakani, K. Rezaei, Comparison of microwave-assisted hydrodistillation with the traditional hydrodistillation method in the extraction of essential oils from Thymus vulgaris L., Food Chem. 109 (2008) 925-930

[66] J. M. Prieto, P. Iacopini, P. Cioni, S. Chericoni, In vitro activity of the essential oils of Origanum vulgare, Satureja montana and their main constituents in peroxynitrite-induced oxidative processes, Food Chem. 104 (2007) 889-895

[67] L. Pérez-Fons, F. J. Aranda, J. Guillén, J. Villalaín, V Micol, Rosemary (Rosmarinus officinalis) diterpenes affect lipid polymorphism and fluidity in phospholipid membranes, Arch. Biochem. Biophys. 453 (2006) 224-236

[68] K. Brady, C.-T. Ho, R. T. Rosen, S. Sang, M. V. Karwe, Effects of processing on the nutraceutical profile of quinoa, Food Chem. 100 (2007) 1209-1216

[69] B. Casado, M. Affolter, M. Kussmann, OMICS-rooted studies of milk proteins, oligosaccharides and lipids, J. Proteomics 73 (2009) 196-208

[70] R. Lacomba, J. Salcedo, A. Alegría, M. J. Lagarda, R. Barberá, E. Matencio, Determination of sialic acid and gangliosides in biological samples and dairy products: A review, J. Pharmaceut. Biomed. 51 (2010) 346-357

[71] I. Mocchetti, Exogenous gangliosides, neuronal plasticity and repair, and the neurotrophins. Cell. Mol. Life Sci. 62 (2005) 2283-2294 
[72] P. Dugo, M. Herrero, T. Kumm, D. Giuffrida, G. Dugo, L. Mondello, Comprehensive normal-phasexreversed-phase liquid chromatography coupled to photodiode array and mass spectrometry detection for the analysis of free carotenoids and carotenoid esters from mandarin, J. Chromatogr. A, 1189 (2008) 196-206 [73] P. Dugo, D. Giuffrida, M. Herrero, P. Donato, L. Mondello, Epoxycarotenoids esters analysis in intact orange juices using two-dimensional comprehensive liquid chromatography, J. Sep. Sci. 32 (2009) 973 - 980

842 [74] R. Charoensiri, R. Kongkachuichai , S. Suknicom, P. Sungpuag, $\beta$-carotene, lycopene, and $\alpha$-tocopherol contents of selected Thai fruits, Food Chem. 113 (2009) 202-207

[75] M.d.C.B.M. de Vasconcelos, R.N. Bennett, S. Quideau, R. Jacquet, E.A.S. Rosa, J.V. Ferreira-Cardoso, Evaluating the potential of chestnut (Castanea sativa Mill.) fruit pericarp and integument as a source of tocopherols, pigments and polyphenols, Ind. Crops Prod., 31 (2010) 301-311.

[76] M. Fazel, M. A. Sahari, M. Barzegar, Determination of main tea seed oil antioxidants and their effects on common kilka oil, Int. Food. Res. J. 15 (2) (2008) 209-217

[77] B. P. Nobre, F. Marcelo, R. Passos, L. Beiráo, A. Palabra, L. Gouveia, R. Mendes, Supercritical carbon dioxide extraction of astaxanthin and other carotenoids from the microalga Haematococcus pluvialis. Eur. Food Technol. 223 (2006) 787-790

[78] L. Jaime, J. A. Mendiola, E. Ibáñez, P. J. Martin-Alvarez, A. Cifuentes, G, Reglero, F. J. Señoráns, $\beta$-carotene isomer composition of sub- and supercritical carbon dioxide extracts of Dunaliella salina microalga. Antioxidant activity measurement, J. Agric. Food Chem. 55 (2007) 10585-10590

[79] M. Herrero, L. Jaime, P.J. Martin-Alvarez, A. Cifuentes, E. Ibanez, Optimization of the extraction of antioxidants from Dunaliella salina microalga by pressurized liquids, J. Agric. Food Chem., 54 (2006) 5597-5603.

[80] D. Naviglio, T. Caruso, P. Iannece, A. Aragón, A. Santini, Characterization of high purity lycopene from tomato wastes using a new pressurized extraction approach, J. Agric. Food Chem. 56 (2008) 6227-6231

[81] G. Giovanelli, E. Pagliarini, Antioxidant composition of tomato products typically consumed in Italy. Ita. J. Food Sci. 21(3) (2009) 305-316

[82] J. D. Vasta, J. Sherma, Analysis of lycopene in nutritional supplements by silica gel high-performance thin-layer chromatography with visible-mode densitometry, Acta Chromatogr. 20 (4) (2008) 673-683

[83] P. Benatti, G. Peluso, R. Nicolai, M. Calvani, Polyunsaturated fatty acids: biochemical, nutritional and epigenetic properties. J. Am. Coll. Nutr. 23 (2004) 281-302

[84] C. Von Schacky, The role of Omega-3 fatty acids in cardiovascular disease. Curr. Atheroscler. Rep. 5 (2003) 139-145

[85] A. C. Patterson, K. D. Stark, Direct determinations of the fatty acid composition of daily dietary intakes incorporating nutraceuticals and functional food strategies to increase n-3 highly unsaturated fatty acids, J.Am. Coll. Nutr. 27(5) (2008) 538-546

[86] M. Aranda, G. Morlock, Simultaneous determination of riboflavin, pyridoxine, nicotinamide, caffeine and taurine in energy drinks by planar chromatography-multiple detection with confirmation by electrospray ionization mass spectrometry, J. Chromatogr. A, 1131 (2006) 253-260

[87] C. M. López-Ortiz, S. Prats-Moya, A. Beltrán Sanahuja, S. E. Maestre-Pérez, N. GranéTeruel, M. L. Martín-Carratala, Comparative study of tocopherol homologue content in fourlmond oil cultivars during two consecutive years, J. Food Compos. Anal. 21 (2008) 144151

[88] P. Sookwong, K. Nakagawa, K. Murata, Y. Kojima, T. Miyazawa, Quantitation of tocotrienol and tocopherol in various rice brans, J. Agric. Food Chem. 55 (2007) 461-466 
[89] G. Oms-Oliu, I. Odriozola-Serrano, R. Soliva-Fortuny, O. Martín-Belloso, Antioxidant content of fresh-cut pears stored in high- $\mathrm{O}_{2}$ active packages compared with conventional low$\mathrm{O}_{2}$ active and passive modified atmosphere packaging, J. Agric. Food Chem., 56 (2008) 932940.

889

890

891

892

893

894

895

896

897

898

899

900

901

902

903

904

905

906

907

908

909

910

911

912

913

914

915

916

917

918

919

920

921

922

923

924

925

926

927

928

929

930

931

932

933

934 [90] J. A. Mendiola, D. García-Martínez, F. J. Rupérez, P. J. Martín-Alvarez, G. Reglero, A. platensis microalga by SFE, J. Supercrit. Fluid. 43 (2008) 484-489

[91] R. P. Zanes Furlani, H. Teixeira Godoy, Vitamins B1 and B2 contents in cultivated mushrooms, Food Chem. 106 (2008) 816-819

[92] A. Gentili, F. Caretti, G. D’Ascenzo, S. Marchese, D. Perret, D. Di Corcia, L. Mainero Rocca, Simultaneous determination of water-soluble vitamins in selected food matrices by liquid chromatography/electrospray ionization tandem mass spectrometry, Rapid Commun. Mass Spectrom. 22 (2008) 2029-2043

[93] H. Borochov-Neori, S. Judeinstein, A. Greenberg, B. Fuhrman, J. Attias, Nina Volkova, T. Hayek, M. Aviram, Phenolic antioxidants and antiatherogenic effects of marula (Sclerocarrya birrea Subsp. caffra) fruit juice in healthy humans, J. Agric. Food Chem. 56 (2008) 9884-9891

[94] R. González-Montelongo, M.G. Lobo, M. González, Antioxidant activity in banana peel extracts: Testing extraction conditions and related bioactive compounds, Food Chem., 119 (2010) 1030-1039.

[95] S.J. Kim, C. Kawaharada, T. Suzuki, K. Saito, N. Hashimoto, S. Takigawa, T. Noda, C. Matsuura-Endo, H. Yamauchi, Effect of natural light periods on rutin, free amino acid and vitamin $\mathrm{C}$ contents in the sprouts of common (Fagopyrum esculentum Moench) and tartary (F. tataricum Gaertn.) buckwheats, Food Sci. Technol. Res., 12 (2006) 199-205.

[96] W.-J. Kim, J. Kim, B. Veriansyah, J.-D. Kim, Y.-W. Lee, S.-G. Oh, R. R. Tjandrawinata, Extraction of bioactive components from Centella asiatica using subcritical water, J. Supercrit. Fluid. 48 (2009) 211-216

[97] J.A. Mendiola, F.R. Marin, F.J. Señorans, G. Reglero, P.J. Martín-Álvarez, A. Cifuentes, E. Ibáñez, Profiling of different bioactive compounds in functional drinks by highperformance liquid chromatography, J. Chromatogr. A, 1188 (2008) 234-241.

[98] G. Oms-Oliu, I. Odriozola-Serrano, R. Soliva-Fortuny, Olga Martín-Belloso, Antioxidant content of fresh-cut pears stored inhigh- $\mathrm{O}_{2}$ active packages compared with conventional low$\mathrm{O}_{2}$ active and passive modified atmosphere packaging, J. Agric. Food Chem. 56 (2008) 932940

[99] L. Campanella, E. Martini, M. Pintore, M. Tomassetti, Determination of lactoferrin and immunoglobulin G in animal milks by new immunosensors, Sensors 9 (2009) 2202-2221

[100] Ma . M. Contreras, I. López-Expósito, B. Hernández-Ledesma, M. Ramos, I. Recio, Application of mass spectrometry to the characterization and quantification of food bioactive peptides, J. AOAC Int. 91 (4) (2008) 981-994

[101] J. Meltretter, A. Schmidt, A. Humeny, C.-M. Becker, M. Pischetsrieder, Analysis of the peptide profile of milk and its changes during thermal treatment and storage, J. Agric. Food Chem. 56 (2008) 2899-2906

[102] C. De Simone, G. Picariello, G. Mamone, P. Stiuso, A. Dicitore, D. Vanacore, L. Chianese, F. Addeo, P. Ferranti, Characterisation and cytomodulatory properties of peptides from Mozzarella di Bufala Campana cheese whey, J. Pept. Sci. 15 (2009) 251-258

[103] M. Herrero, E. Ibáñez S. Fanali, A. Cifuentes, Quantitation of chiral amino acids from microalgae by MEKC and LIF detection, Electrophoresis 28 (2007) 2701-2709

[104] Y. V. Yuan, N. D. Westcott, C. Hu, D. D. Kitts, Mycosporine-like amino acid composition of the edible red alga, Palmaria palmata (dulse) harvested from the west and east coasts of Grand Manan Island, New Brunswick, Food Chem. 112 (2009) 321-328 
[105] H. Ueno, J. Wang, N. Kaji, M. Tokeshi, Y. Baba, Quantitative determination of amino acids in functional foods by microchip electrophoresis, J. Sep. Sci. 31 (2008) 898 - 903

[106] L. Beaulieu, J. Thibodeau, P. Bryl, M.-E. Carbonneau, Proteolytic processing of herring (Clupea harengus): biochemical and nutritional characterisation of hydrolysates, Int. J. Food Sci. Technol. 44 (2009) 44, 2113-2119

[107] A. Bougatef, N. Nedjar-Arroume, L. Manni, R. Ravallec, A. Barkia, D. Guillochon, M. Nasri, Purification and identification of novel antioxidant peptides from enzymatic hydrolysates of sardinelle (Sardinella aurita) by-products proteins, Food Chem. 118 (2010) 559-565

[108] J.-Y. Je, Z.-J. Qian, H.-G. Byun, S.-K. Kim, Purification and characterization of an antioxidant peptide obtained from tuna backbone protein by enzymatic hydrolysis, Process Biochem. 42 (2007) 840-846

[109] H.-Y. Jo, W.-K. Jung, S.-K. Kim, Purification and characterization of a novel anticoagulant peptide from marine echiuroid worm, Urechis unicinctus, Process Biochem. 43 (2008) 179-184

[110] S.-H. Lee, Z.-J. Qian, S.-K. Kim, A novel angiotensin I converting enzyme inhibitory peptide from tuna frame protein hydrolysate and its antihypertensive effect in spontaneously hypertensive rats, Food Chem. 118 (2010) 96-102

[111] H. Cao, S.-Y. Xu, Purification and characterization of type II collagen from chick sternal cartilage, Food Chem. 108 (2008) 439-445

[112] M. B. Ningappa, L. Srinivas, Purification and characterization of $\sim 35 \mathrm{kDa}$ antioxidant protein from curry leaves (Murraya koenigii L.), Toxicol. in Vitro 22 (2008) 699-709

[113] F. Clement, S. N. Pramod, Y. P. Venkatesh, Identity of the immunomodulatory proteins from garlic (Allium sativum) with themajor garlic lectins or agglutinins, Int. Immunopharmacol. 10 (2010) 316-324

[114] R. Saltarelli, P. Ceccaroli, M. Iotti, A. Zambonelli, M. Buffalini, L. Casadei, L. Vallorani, V. Stocchi, Biochemical characterisation and antioxidant activity of mycelium of Ganoderma lucidum from Central Italy, Food Chem. 116 (2009) 143-151

[115] S.-J. You, C. C. Udenigwe, R. E. Aluko, J. Wu, Multifunctional peptides from egg white lysozyme, Food Res. Int. 43 (2010) 848-855

[116] Ö. Güclü-Üstündağ, G. Mazza, Extraction of saponins and cyclopeptides from cow cockle seed with pressurized low polarity water, Food Sci. Technol. 41 (2008) 1600-1606

[117] M. Mosca, C. Boniglia, B. Carratù , S. Giammarioli, V. Nera, E. Manzini, Determination of $\alpha$-amylase inhibitor activity of phaseolamin from kidney bean (Phaseolus vulgaris) in dietary supplements by HPAEC-PAD, Anal. Chim. Acta 617 (2008) 192-195

[118] M. Dernovics, P. Giusti, R. Lobinski, ICP-MS-assisted nanoHPLC-electrospray Q/timeof-flight MS/MS selenopeptide mapping in Brazil nuts, J. Anal. At. Spectrom. 22 (2007) 4150

[119] C. J. Malavaki, A. P. Asimakopoulou, F. N. Lamari, A. D. Theocharis, G. N. Tzanakakis, N. K. Karamanos, Capillary electrophoresis for the quality control of chondroitin sulfates in raw materials and formulations, Anal. Biochem. 374 (2008) 213-220

[120] J.-S. Sim, A.-R. Im, S. M. Cho, H. J. Jang, J. H. Jo, Y. S. Kim, Evaluation of chondroitin sulfate in shark cartilage powder as a dietary supplement: Raw materials and finished products, Food Chem. 101 (2007) 532-539

[121] N. Volpi, F. Maccari, Quantitative and qualitative evaluation of chondroitin sulfate in dietary supplements, Food Anal. Methods 1 (2008) 195-204

[122] M.-K. Lu, J.-J. Cheng, C.-Y. Lin, C.-C. Chang, Purification, structural elucidation, and anti-inflammatory effect of a water-soluble 1,6-branched 1,3- $\alpha$-D-galactan from cultured mycelia of Poria cocos, Food Chem. 118 (2010) 349-356 
984

985

986

987

988

989

990

991

992

993

994

995

996

997

998

999

1000

1001

1002

1003

1004

1005

1006

1007

1008

1009

1010

1011

1012

1013

1014

1015

1016

1017

1018

1019

1020

1021

1022

1023

1024

1025

1026

1027

1028

1029

1030

1031

1032

1033

[123] M. Sójk, B. Król, Composition of industrial seedless black currant pomace, Eur. Food Res. Technol. (2009) 228:597-605

[124] F. Montañés, A. Olano, G. Reglero, E. Ibáñez, T. Fornari, Supercritical technology as an alternative to fractionate prebiotic galactooligosaccharides, Sep. Purif. Technol. 66 (2009) 383-389.

[125] N. Volpi, Capillary electrophoresis determination of glucosamine in nutraceutical formulations after labeling with anthranilic acid and UV detection, J. Pharmaceut. Biomed. Anal. 49 (2009) 868-871

[126] J.-J. Chen, Y. C. Lee, T.-J. Cheng, H.-Y. Hsiao, R. L. C. Chen, Determination of glucosamine content in nutraceuticals by capillary electrophoresis using in-capillary OPA labeling techniques, J. Food Drug Anal. 14 (2) (2006) 203-206

[127] A. Erkucuk, I. H. Akgun, O. Yesil-Celiktas, Supercritical $\mathrm{CO}_{2}$ extraction of glycosides from Stevia rebaudiana leaves: Identification and optimization, J. Supercrit. Fluid. 51 (2009) 29-35

[128] L. F. D’Antuono, S. Elementi, R. Neri, Glucosinolates in Diplotaxis and Eruca leaves: Diversity, taxonomic relations and applied aspects, Phytochemistry 69 (2008) 187-199

[129] J.-Y. Baek, J.-M. Lee, S.-C. Lee, Extraction of nutraceutical compounds from licorice roots with subcritical water, Sep. Purif. Technol. 63 (2008) 661-664

[130] S. Dall'Acqua, G. Innocenti, Steroidal glycosides from Hoodia gordonii, Steroids 72 (2007) 559-568

[131] T. Li, Z. Zhang, L. Zhang, X. Huang, J. Lin, G. Chen, An improved facile method for extraction and determination of steroidal saponins in Tribulus terrestris by focused microwaveassisted extraction coupled with GC-MS, J. Sep. Sci. 32 (2009) 4167-4175

[132] H. Kimura, S. Ogawa, M. Jisaka, Y. Kimura, T. Katsube, K. Yokota, Identification of novel saponins from edible seeds of Japanese horse chestnut (Aesculus turbinata Blume) after treatment with wooden ashes and their nutraceutical activity, J. Pharmaceut. Biomed. 41 (2006) 1657-1665

[133] Ø.M. Andersen, K.R. Markham, Flavonoids: chemistry, biochemistry, and applications, 2nd ed., CRC Press, Boca Raton, FL, USA, 2007.

[134] W.J. Hurst, Methods of Analysis for Functional Foods and Nutraceuticals, 1st ed., CRC Press, Boca Ratón, FL, USA, 2002.

[135] T. Tsuda, F. Horio, K. Uchida, H. Aoki, T. Osawa, Dietary cyanidin 3-O-b-Dglucoside-rich purple corn color prevents obesity and ameliorates hyperglycemia in mice, J. Nutr., 133 (2003) 2125-2130.

[136] Y.C. Hsiao, Y.S. Hsieh, W.H. Kuo, H.L. Chiou, S.F. Yang, W.L. Chiang, S.C. Chu, The tumor-growth inhibitory activity of flavanone and 2-OH flavanone in vitro and in vivo through induction of cell cycle arrest and suppression of cyclins and CDKs, J. Biomed. Sci., 14 (2007) 107-119.

[137] J. Vanamala, T. Leonardi, B.S. Patil, S.S. Taddeo, M.E. Murphy, L.M. Pike, R.S. Chapkin, J.R. Lupton, N.D. Turner, Suppression of colon carcinogenesis by bioactive compounds in grapefruit, Carcinogenesis, 27 (2006) 1257-1265.

[138] C.A. De La Lastra, I. Villegas, Resveratrol as an anti-inflammatory and anti-aging agent: Mechanisms and clinical implications, Mol. Nutr. Food Res., 49 (2005) 405-430.

[139] G. Zhang, L. Qin, H. Sheng, X.L. Wang, Y.X. Wang, D.K.W. Yeung, J.F. Griffith, X.S. Yao, X.H. Xie, Z.R. Li, K.M. Lee, K.S. Leung, A novel semisynthesized small molecule icaritin reduces incidence of steroid-associated osteonecrosis with inhibition of both thrombosis and lipid-deposition in a dose-dependent manner, Bone, 44 (2009) 345-356.

[140] N. Carusio, R. Wangensteen, A. Filippelli, R. Andriantsitohaina, Oral administration of polyphenolic compounds from cognac decreases ADP-induced platelet aggregation and reduces chronotropic effect of isoprenaline in rats, Physiol. Res., 57 (2008) 517-524. 
[141] S.O. Agboola, O.A. Mofolasayo, B.M. Watts, R.E. Aluko, Functional properties of yellow field pea (Pisum sativum L.) seed flours and the in vitro bioactive properties of their polyphenols, Food Res. Int., 43 (2010) 582-588. [142] M.A. Al-Farsi, C.Y. Lee, Optimization of phenolics and dietary fibre extraction from date seeds, Food Chem., 108 (2008) 977-985. [143] V. Amico, R. Chillemi, S. Mangiafico, C. Spatafora, C. Tringali, Polyphenol-enriched fractions from Sicilian grape pomace: HPLC-DAD analysis and antioxidant activity, Bioresour. Technol., 99 (2008) 5960-5966.

[144] S. Butsat, S. Siriamornpun, Antioxidant capacities and phenolic compounds of the husk, bran and endosperm of Thai rice, Food Chem., 119 (2010) 606-613.

[145] A. Del Caro, A. Piga, Polyphenol composition of peel and pulp of two Italian fresh fig fruits cultivars (Ficus carica L.), Eur. Food Res. Technol., 226 (2008) 715-719.

[146] S.H. Guzmán-Maldonado, G. Herrera-Hernández, D. Hernández-López, R. ReynosoCamacho, A. Guzmán-Tovar, F. Vaillant, P. Brat, Physicochemical, nutritional and functional characteristics of two underutilised fruit cactus species (Myrtillocactus) produced in central Mexico, Food Chem., 121 (2010) 381-386.

[147] S. Moreno, T. Scheyer, C.S. Romano, A.n.A. Vojnov, Antioxidant and antimicrobial activities of rosemary extracts linked to their polyphenol composition, Free Radical Res., 40 (2006) 223-231.

[148] J.M. Peñarrieta, J.A. Alvarado, B. Akesson, B. Bergenstal, Total antioxidant capacity and content of flavonoids and other phenolic compounds in canihua (Chenopodium pallidicaule): An Andean pseudocereal, Mol. Nutr. Food Res., 52 (2008) 708-717.

[149] S. Rakic, S. Petrovic, J. Kukic, M. Jadranin, V. Tesevic, D. Povrenovic, S. SilerMarinkovic, Influence of thermal treatment on phenolic compounds and antioxidant properties of oak acorns from Serbia, Food Chem., 104 (2007) 830-834.

[150] I. Rodríguez-Meizoso, F.R. Marin, M. Herrero, F.J. Señorans, G. Reglero, A. Cifuentes, E. Ibáñez, Subcritical water extraction of nutraceuticals with antioxidant activity from oregano. Chemical and functional characterization, J. Pharm. Biomed. Anal., 41 (2006) 15601565 .

[151] E.B. Saafi, A. El Arem, M. Issaoui, M. Hammami, L. Achour, Phenolic content and antioxidant activity of four date palm (Phoenix dactylifera L.) fruit varieties grown in Tunisia, Int. J. Food Sci. Technol., 44 (2009) 2314-2319.

[152] A. Siger, M. Nogala-Kalucka, E. Lampart-Szczapa, The content and antioxidant activity of phenolic compounds in cold-pressed plant oils, J. Food Lipids, 15 (2008) 137-149.

[153] A.A. Soares, C.G.M. de Souza, F.M. Daniel, G.P. Ferrari, S.M.G. da Costa, R.M. Peralta, Antioxidant activity and total phenolic content of Agaricus brasiliensis (Agaricus blazei Murril) in two stages of maturity, Food Chem., 112 (2009) 775-781.

[154] M. Sójka, B. Król, Composition of industrial seedless black currant pomace, Eur. Food Res. Technol., 228 (2009) 597-605.

[155] A. Solar, R. Veberic , L. Bacchetta, R. Botta, P. Drogoudi, I. Metzidakis, M. Rovira, J.P. Sarraquigne, A.P. Silva, Phenolic characterization of some hazelnut cultivars from different European germplasm collections, Acta Horticulturae, 845 (2009) 613-618.

[156] D. Sun-Waterhouse, I. Wen, R. Wibisono, L.D. Melton, S. Wadhwa, Evaluation of the extraction efficiency for polyphenol extracts from by-products of green kiwifruit juicing, Int. J. Food Sci. Technol., 44 (2009) 2644-2652.

[157] B. Abad-García, L.A. Berrueta, S. Garmón-Lobato, B. Gallo, F. Vicente, A general analytical strategy for the characterization of phenolic compounds in fruit juices by highperformance liquid chromatography with diode array detection coupled to electrospray ionization and triple quadrupole mass spectrometry, J. Chromatogr. A, 1216 (2009) 53985415. 
1084 [158] M.J. Anttonen, R.O. Karjalainen, High-Performance Liquid Chromatography Analysis of Black Currant (Ribes nigrum L.) Fruit Phenolics Grown either Conventionally or Organically, J. Agric. Food Chem., 54 (2006) 7530-7538. [159] C. Fredes, Antioxidants in Chilean native berries, Bol Latinoam. Caribe Plant Med Aromat, 8 (2009) 469 - 478. [160] S. Fu, A. Segura-Carretero, D. Arráez-Román, J.A. Menéndez, A. De La Torre, A. Fernández-Gutiérrez, Tentative characterization of novel phenolic compounds in extra virgin Agric. Food Chem., 57 (2009) 11140-11147.

[161] R. Japón Luján, F. Priego Capote, A. Marinas, M.D. Luque de Castro, Liquid chromatography/triple quadrupole tandem mass spectrometry with multiple reaction monitoring for optimal selection of transitions to evaluate nutraceuticals from olive-tree materials, Rapid Commun. Mass Spectrom., 22 (2008) 855-864.

[162] P. Liu, B. Yang, H. Kallio, Characterization of phenolic compounds in Chinese hawthorn (Crataegus pinnatifida Bge. var. major) fruit by high performance liquid chromatography-electrospray ionization mass spectrometry, Food Chem., 121 (2010) 11881197.

[163] I. Nicoletti, C. Bello, A. De Rossi, D. Corradini, Identification and quantification of phenolic compounds in grapes by HPLC-PDA-ESI-MS on a semimicro separation scale, J. Agric. Food Chem., 56 (2008) 8801-8808.

[164] G. Shui, L.P. Leong, Residue from star fruit as valuable source for functional food ingredients and antioxidant nutraceuticals, Food Chem., 97 (2006) 277-284.

[165] U. Thiyam, P. Claudia, U. Jan, B. Alfred, De-oiled rapeseed and a protein isolate: Characterization of sinapic acid derivatives by HPLC-DAD and LC-MS, Eur. Food Res. Technol., 229 (2009) 825-831.

[166] W. Zhang, F. Han, J. He, C. Duan, HPLC-DAD-ESI-MS/MS Analysis and Antioxidant Activities of Nonanthocyanin Phenolics in Mulberry (Morus alba L.), J. Food Sci., 73 (2008) C512-C518.

[167] H. Alighourchi, M. Barzegar, S. Abbasi, Anthocyanins characterization of 15 Iranian pomegranate (Punica granatum L.) varieties and their variation after cold storage and pasteurization, Eur. Food Res. Technol., 227 (2008) 881-887.

[168] M. Bononi, F. Tateo, Stabilization of cranberry anthocyanins in nutraceutical capsules, Int. J. Food Sci. Nutr., 58 (2007) 142-149.

[169] F.S. Hosseinian, W. Li, T. Beta, Measurement of anthocyanins and other phytochemicals in purple wheat, Food Chem., 109 (2008) 916-924.

[170] L. Jakobek, M. Seruga, M. Medvidovic-Kosanovic, I. Novak, Anthocyanin content and antioxidant activity of various red fruit juices, Dtsch. Lebens. Runds., 103 (2007) 58-64.

[171] J. Lee, C. Rennaker, R.E. Wrolstad, Correlation of two anthocyanin quantification methods: HPLC and spectrophotometric methods, Food Chem., 110 (2008) 782-786.

[172] S. Tural, I. Koca, Physico-chemical and antioxidant properties of cornelian cherry fruits (Cornus mas L.) grown in Turkey, Sci. Hort., 116 (2008) 362-366.

[173] Y. Yan, Z. Li, M.A.G. Koffas, High-yield anthocyanin biosynthesis in engineered Escherichia coli, Biotechnol. Bioeng., 100 (2008) 126-140.

[174] R. Chirinos, D. Campos, I. Betalleluz, M.M. Giusti, S.J. Schwartz, Q. Tian, R. Pedreschi, Y. Larondelle, High-Performance Liquid Chromatography with Photodiode Array Detection (HPLC-DAD)/HPLC-Mass Spectrometry (MS) Profiling of Anthocyanins from Andean Mashua Tubers (Tropaeolum tuberosum Ruíz and Pavón) and Their Contribution to the Overall Antioxidant Activity, J. Agric. Food Chem., 54 (2006) 7089-7097. 
[175] G.A. Garzón, K.M. Riedl, S.J. Schwartz, Determination of Anthocyanins, Total Phenolic Content, and Antioxidant Activity in Andes Berry (Rubus glaucus Benth), J. Food Sci., 74 (2009) C227-C232. in Australian Native Fruits. Identification and Quantification of Anthocyanins, J. Agric. Food Chem., 54 (2006) 9820-9826.

[177] C. Vasco, K. Riihinen, J. Ruales, A. Kamal-Eldin, Phenolic compounds in rosaceae fruits from Ecuador, J. Agric. Food Chem., 57 (2009) 1204-1212. on the fragmentation and differentiation of $\mathrm{C}$-glycosidic flavone isomers by positive electrospray ionization and triple quadrupole mass spectrometry, Rapid Commun. Mass Spectrom., 22 (2008) 1834-1842.

1144 [179] A.A. Barba, A. Calabretti, M. d'Amore, A.L. Piccinelli, L. Rastrelli, Phenolic constituents levels in cv. Agria potato under microwave processing, LWT--Food Sci. Technol., 41 (2008) 1919-1926.

[180] A. Brettonnet, A. Hewavitarana, S. DeJong, M.C. Lanari, Phenolic acids composition and antioxidant activity of canola extracts in cooked beef, chicken and pork, Food Chem., 121 (2010) 927-933.

[181] G. Dinelli, A. Bonetti, M. Minelli, I. Marotti, P. Catizone, A. Mazzanti, Content of flavonols in Italian bean (Phaseolus vulgaris L.) ecotypes, Food Chem., 99 (2006) 105-114. [182] R.P. Feliciano, M.N. Bravo, M.M. Pires, A.T. Serra, C.M. Duarte, L.V. Boas, M.R. Bronze, Phenolic content and antioxidant activity of moscatel dessert wines from the set $\tilde{A}^{\circ}$ bal region in portugal, Food Anal. Meth., 2 (2009) 149-161.

[183] A. Fiorentino, A. Ricci, B. D'Abrosca, S. Pacifico, A. Golino, M. Letizia, S. Piccolella, P. Monaco, Potential food additives from Carex distachya roots: Identification and in vitro antioxidant properties, J. Agric. Food Chem., 56 (2008) 8218-8225.

[184] C.E. Green, S.L. Hibbert, Y.A. Bailey-Shaw, L.A.D. Williams, S. Mitchell, E. Garraway, Extraction, Processing, and Storage Effects on Curcuminoids and Oleoresin Yields from Curcuma longa L. Grown in Jamaica, J. Agric. Food Chem., 56 (2008) 3664-3670.

[185] C.H.L. Ho, J.E. Cacace, G. Mazza, Mass transfer during pressurized low polarity water extraction of lignans from flaxseed meal, J. Food Eng., 89 (2008) 64-71.

[186] F.S. Hosseinian, G. Mazza, Triticale bran and straw: Potential new sources of phenolic acids, proanthocyanidins, and lignans, J. Funct. Foods, 1 (2009) 57-64.

[187] M.J. Jung, S.-I. Heo, M.-H. Wang, HPLC analysis and antioxidant activity of Ulmus davidiana and some flavonoids, Food Chem., 120 (2010) 313-318.

[188] E. Karacabey, G. Mazza, Optimization of solid-liquid extraction of resveratrol and other phenolic compounds from milled grape canes (Vitis vinifera), J. Agric. Food Chem., 56 (2008) 6318-6325.

[189] J.-T. Lin, S.-C. Liu, G.J. Tsay, D.-J. Yang, Composition of flavonoids and phenolic acids in Glycin tomentella Hayata cultivated in various soils, Food Chem., 121 (2010) 659665.

[190] A.A. Memon, N. Memon, D.L. Luthria, M.I. Bhanger, A.A. Pitafi, Phenolic acids profiling and antioxidant potential of mulberry (Morus laevigata W., Morus nigra L., Morus alba L.) Leaves and fruits grown in Pakistan, Pol. J. Food Nutr. Sci., 60 (2010) 25-32.

[191] G. Nuissier, B. Rezzonico, M. Grignon-Dubois, Chicoric acid from Syringodium filiforme, Food Chem., 120 (2010) 783-788.

[192] J. Prokop, P. Abrman, A.L. Seligson, M. Sovak, Resveratrol and its glycon piceid are stable polyphenols, J. Med. Food, 9 (2006) 11-14.

[193] Y. Qiu, Q. Lin, T. Beta, Antioxidant activity of commercial wild rice and identification of flavonoid compounds in active fractions, J. Agric. Food Chem., 57 (2009) 7543-7551. 
[194] Y. Qiu, Q. Liu, T. Beta, Antioxidant properties of commercial wild rice and analysis of soluble and insoluble phenolic acids, Food Chem., 121 (2010) 140-147.

[195] T. Radjabian, S. Rezazadeh, H.F. Huseini, Analysis of silymarin components in the seed extracts of some milk thistle ecotypes from Iran by HPLC, Iran. J. Sci. Technol. A, 32 (2008) 141-146.

[196] G. Rak, P. Fodor, L. Abrankó, Three-step HPLC-ESI-MS/MS procedure for screening and identifying non-target flavonoid derivatives, Int. J. Mass spectrom., 290 (2010) 32-38. [197] A.P. Singh, T. Wilson, A.J. Kalk, J. Cheong, N. Vorsa, Isolation of specific cranberry flavonoids for biological activity assessment, Food Chem., 116 (2009) 963-968.

[198] G. Sivakumar, C.B. Bati, N. Uccella, Demethyloleuropein and b-glucosidase activity in olive fruits, Biotechnol. J., 2 (2007) 381-385.

[199] M.T.S. Trevisan, B. Pfundstein, R. Haubner, G. Würtele, B. Spiegelhalder, H. Bartsch, R.W. Owen, Characterization of alkyl phenols in cashew (Anacardium occidentale) products and assay of their antioxidant capacity, Food Chem. Toxicol., 44 (2006) 188-197.

[200] Y. Wei, Q. Xie, W. Dong, Y. Ito, Separation of epigallocatechin and flavonoids from Hypericum perforatum L. by high-speed counter-current chromatography and preparative high-performance liquid chromatography, J. Chromatogr. A, 1216 (2009) 4313-4318.

[201] B. Xu, S.K.C. Chang, Total phenolics, phenolic acids, isoflavones, and anthocyanins and antioxidant properties of yellow and black soybeans as affected by thermal processing, J. Agric. Food Chem., 56 (2008) 7165-7175.

[202] S. Chatterjee, Z. Niaz, S. Gautam, S. Adhikari, P.S. Variyar, A. Sharma, Antioxidant activity of some phenolic constituents from green pepper (Piper nigrum L.) and fresh nutmeg mace (Myristica fragrans), Food Chem., 101 (2007) 515-523.

[203] J. Pejin, O. Grujic, J. Canadanovic-Brunet, D. Vujic, V. Tumbas, Investigation of phenolic acids content and antioxidant activity in malt production, J. Am. Soc. Brew. Chem., 67 (2009) 81-88.

[204] F. Shadkami, S. Estevez, R. Helleur, Analysis of catechins and condensed tannins by thermally assisted hydrolysis/methylation-GC/MS and by a novel two step methylation, J. Anal. Appl. Pyrolysis, 85 (2009) 54-65.

[205] R. Zadernowski, S. Czaplicki, M. Naczk, Phenolic acid profiles of mangosteen fruits (Garcinia mangostana), Food Chem., 112 (2009) 685-689.

[206] K. Dhalwal, V.M. Shinde, Y.S. Biradar, K.R. Mahadik, Simultaneous quantification of bergenin, catechin, and gallic acid from Bergenia ciliata and Bergenia ligulata by using thinlayer chromatography, J. Food Comp. Anal., 21 (2008) 496-500.

[207] U.K. Sharma, N. Sharma, A.P. Gupta, V. Kumar, A.K. Sinha, RP-HPTLC densitometric determination and validation of vanillin and related phenolic compounds in accelerated solvent extract of Vanilla planifolia, J. Sep. Sci., 30 (2007) 3174-3180.

[208] F. Berli, J. D'Angelo, B. Cavagnaro, R. Bottini, R. Wuilloud, M.F. Silva, Phenolic composition in grape (Vitis vinifera L. cv. Malbec) ripened with different solar UV-B radiation levels by capillary zone electrophoresis, J. Agric. Food Chem., 56 (2008) 28922898.

[209] L. Chi, Z. Li, S. Dong, P. He, Q. Wang, Y. Fang, Simultaneous determination of flavonoids and phenolic acids in Chinese herbal tea by beta-cyclodextrin based capillary zone electrophoresis, Microchimica Acta, 167 (2009) 179-185.

[210] S. Orlandini, I. Giannini, S. Pinzauti, S. Furlanetto, Multivariate optimisation and validation of a capillary electrophoresis method for the analysis of resveratrol in a nutraceutical, Talanta, 74 (2008) 570-577.

1230 phenolic compounds in grape skin by capillary electrophoresis with simultaneous dual 
1231 fluorescence and diode array absorption detection after dynamic superheated liquid leaching,

1232 J. Chromatogr. A, 1139 (2007) 301-307.

1233 [212] J.Y. Chung, J.H. Choo, M.H. Lee, J.K. Hwang, Anticariogenic activity of macelignan

1234 isolated from Myristica fragrans (nutmeg) against Streptococcus mutans, Phytomedicine, 13

1235 (2006) 261-266.

1236 [213] J.T. Jeong, J.-H. Moon, K.-H. Park, C.S. Shin, Isolation and Characterization of a New

1237 Compound from Prunus mume Fruit that Inhibits Cancer Cells, J. Agric. Food Chem., 54

1238 (2006) 2123-2128.

1239 [214] J.A. Manthey, Fourier transform infrared spectroscopic analysis of the 1240 polymethoxylated flavone content of orange oil residues, J. Agric. Food Chem., 54 (2006) 1241 3215-3218.

1242 [215] I. Rodríguez-Meizoso, A. Cifuentes, J. San Román, E. Ibáñez, C. Elvira, A systematic 1243 study on the interactions between carnosic acid and ethylpyrrolidine methacrylate-methyl 1244 methacrylate copolymer in supercritical media, J. Supercrit. Fluids, 41 (2007) 452-460. [216] S.-R. Won, S.-K. Kim, Y.-M. Kim, P.-H. Lee, J.-H. Ryu, J.-W. Kim, H.-I. Rhee, Licochalcone A: A lipase inhibitor from the roots of Glycyrrhiza uralensis, Food Res. Int., 40 (2007) 1046-1050.

[217] N.Y. Yoon, S.-H. Lee, L. Yong, S.-K. Kim, Phlorotannins from Ishige okamurae and their acetyl- and butyrylcholinesterase inhibitory effects, J. Funct. Foods, 1 (2009) 331-335. [218] C. Boniglia, B. Carratù, R. Gargiulo, S. Giammarioli, M. Mosca, E. Sanzini, Content of phytoestrogens in soy-based dietary supplements, Food Chem., 115 (2009) 1389-1392.

1253 [219] D.E. Gray, R. Upton, A. Chandra, A. Porter, R.K. Harris, Quantitative analysis of flavonol glycosides in Ginkgo biloba: a comparison of two analytical methods, Phytochem. Anal., 17 (2006) 56-62.

[220] S. Jung, P.A. Murphy, I. Sala, Isoflavone profiles of soymilk as affected by highpressure treatments of soymilk and soybeans, Food Chem., 111 (2008) 592-598.

[221] L. Krenn, V. Patsch, An efficient HPLC method for the quantification of isoflavones in soy extracts and soy dietary supplements in routine quality control, Pharmazie, 61 (2006) 582-585.

1260 [222] R. Ksouri, H. Falleh, W. Megdiche, N. Trabelsi, B. Mhamdi, K. Chaieb, A. Bakrouf, C. Magné, C. Abdelly, Antioxidant and antimicrobial activities of the edible medicinal halophyte 1263 2083-2091. [223] S. Li, C.-Y. Lo, C.-T. Ho, Hydroxylated Polymethoxyflavones and Methylated Flavonoids in Sweet Orange (Citrus sinensis) Peel, J. Agric. Food Chem., 54 (2006) 41764185.

[224] L. Li, G.E. Henry, N.P. Seeram, Identification and bioactivities of resveratrol oligomers and flavonoids from carex folliculata Seeds, J. Agric. Food Chem., 57 (2009) 7282-7287.

[225] W. Li, J. Friel, T. Beta, An evaluation of the antioxidant properties and aroma quality of infant cereals, Food Chem., 121 (2010) 1095-1102.

[226] R. Japón Luján, F. Priego Capote, M.D. Luque de Castro, Temporal metabolomic analysis of $\mathrm{O}$-glucoside phenolic compounds and their aglycone forms in olive tree and derived materials, Phytochem. Anal., 20 (2009) 221-230.

[227] M. Oliveira, N. Piovesan, I. José, E. Barros, M. Moreira, L. Oliveira, Protein, Oil, and Isoflavone Contents in Lipoxygenase- and Kunitz Trypsin Inhibitor-Deficient Soybean Seeds, Chromatographia, 66 (2007) 521-527.

[228] N.M.M. Saviranta, M.J. Anttonen, A. Von Wright, R.O. Karjalainen, Red clover (Trifolium pratense L.) isoflavones: Determination of concentrations by plant stage, flower colour, plant part and cultivar, J. Sci. Food Agric., 88 (2008) 125-132. 
1280 [229] M. Stürtz, V. Lander, W. Schmid, P. Winterhalter, Quantitative determination of 1281 isoflavones in soy based nutritional supplements by high-performance liquid chromatography, 1282 J. Verbr. Lebensm., 3 (2008) 127-136.

1283 [230] G. Sivakumar, A. Aliboni, L. Bacchetta, HPLC screening of anti-cancer sulforaphane 1284 from important European Brassica species, Food Chem. 104 (2007) 1761-1764

1285 [231] M. A. Farag, A. A. Motaal, Sulforaphane composition, cytotoxic and antioxidant 1286 activity of crucifer vegetables, J. Adv. Res. 1 (2010) 65-70

1287 [232] K. Kang, K. Lee, S.-O. Sohn, S. Park, S. Lee, S. Y. Kim, Y. S. Kim, K. Back, Ectopic expression of serotonin $\mathrm{N}$-hydroxycinnamoyltransferase and differential production of phenylpropanoid amides in transgenic tomato tissues, Sci. Hortic.-Amsterdam 120 (2009) $1290 \quad 504-510$ [233] G. Jerz, T. N. Arrey, V. Wray, Q. Du, P. Winterhalter, Structural characterization of 132-hydroxy- $\left(13^{2}-S\right)$ phaeophytin-a from leaves and stems of Amaranthus tricolor isolated by high-speed countercurrent chromatography, Inn. Food Sci. Emerg. Technol. 8 (2007) 413-418 [234] E.-O. Chairote, G. Chairote, H. Niamsup, S, Lumyong, The presence and the content of Monacolins in Red Yeast rice prepared from Thai glutinous rice, World J. Microbiol. Biotechnol. 24 (2008) 3039-3047 [235] G.F. Barbero, A. Liazid, M. Palma, C.G. Barroso, Ultrasound-assisted extraction of capsaicinoids from peppers, Talanta 75 (2008) 1332-1337 Heyerick, Hop (Humulus lupulus)-derived bitter acids as multipotent bioactive compounds, J. Nat. Prod. 2009, 72, 1220-1230 


\section{Figure captions}

Figure 1.- Research articles dealing with nutraceutical or functional foods published in the period 1989-2009 (ISI Web of Knowledge, Copyright 2010 Thomson Reuters).

Figure 2.- Chromatograms obtained from the HPLC-UV-QTOF-MS analysis of a selected ethanolic PLE extract obtained from Spirulina platensis, using the UV detector at $280 \mathrm{~nm}$ (A), and the ESIQTOF-MS detector in negative (B) and positive (C) ion modes. Reprinted from [51] with permission from John Wiley and Sons. http://dx.doi.org/10.1002/rcm.3017. Copyright (2007) John Wiley \& Sons, Inc.

Figure 3.- On-line LC-GC analysis of $\gamma$-oryzanol in a crude lipid extract from brown rice. (a) LC chromatogram; UV detection of $\gamma$-oryzanol at $325 \mathrm{~nm}$. The fraction transferred to GC is shown by the indicated time window. (b) GC chromatogram of the $\gamma$-oryzanol-containing fraction; separation of $\gamma$ oryzanol into campesteryl ferulate (1), campestanyl ferulate (2), $\beta$-sitosteryl ferulate (3), cycloartenyl ferulate (4), and 24-methylenecycloartanyl ferulate (5). (I) and (II) were identified as the cotransferred free sterols cycloartenol and 24-methylenecycloartanol. Reprinted from [60] with permission from American Chemical Society. http://dx.doi.org/10.1021/jf061688n Copyright (2006) American Chemical Society.

Figure 4.- (a) Size-exclusion-ICP MS chromatogram of the extracted Brazil nut proteins. Regular line: ${ }^{78} \mathrm{Se}$; thin line: ${ }^{34} \mathrm{~S}$.The rectangular area indicates the fraction collected for further analyses; (b) MALDI-TOF mass spectrum of the fraction indicated in Fig. 4a. The insets show the zooms of the 6 and $12 \mathrm{kDa}$ peaks (doubly and singly charged ions, respectively); (c) size-exclusion-ICP MS chromatogram of the tryptic digest (5 kDa cutoff filtered) of the fraction indicated in Fig. 4a. The arrows mark the elution volumes of the calibration standards. The rectangular fractions labelled with numbers were collected for nanoHPLC analyses. Reprinted from [118]. Reproduced by permission of The Royal Society of Chemistry. http://dx.doi.org/10.1039/b608041c Copyright (2007) The Royal Society of Chemistry.

Figure 5.- MS/MS product ion spectra of $[\mathrm{M}+\mathrm{H}]^{+}$ion of apigenin-8- $C$-glucoside- 4 '- $O$-rhamnoside (cone voltage $30 \mathrm{~V}$, collision energy 20 and $40 \mathrm{eV}$ ). Reprinted from [157] with permission from Elsevier http://dx.doi.org/10.1016/j.chroma.2009.05.039 Copyright (2009) Elsevier B.V.

Figure 6.- FTIR spectum of polymethoxylated flavones (PMFs) in orange peel oil isolated by $95 \%$ ethanol extraction and LH20 column chromatography (A) and spectum of the non-PMF residue recovered after $95 \%$ ethanol extraction (B). The spectra are a summation of eight scans taken with the residue thinly applied to a PTFE IR card. Reprinted from [214] with permission from American Chemical Society. http://dx.doi.org/10.1021/jf053134a Not subject to U.S. Copyright. 
Table 1.- Natural matrices containing fatty acids and analytical techniques employed for their analysis.

\begin{tabular}{|c|c|c|}
\hline Matrix & Analytical techniques & Reference \\
\hline 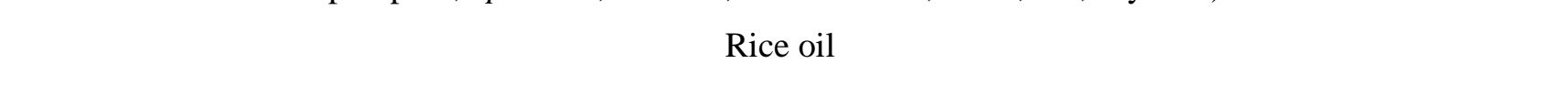 & $\begin{array}{c}\text { GC and HT-GC (FID, MS) } \\
\text { TLC }\end{array}$ & [27-32] \\
\hline Grass-fed and grain-fed beef & GC (FID, MS) & [36] \\
\hline Leuconostoc paramesenteroides, isolated from cheddar cheese & GC-MS & [37] \\
\hline $\begin{array}{c}\text { Alga (Porphyridium cruentum, Himanthalia elongata and Synechocystis s, Chaetoceros muelleri, Chlorella } \\
\text { vulgari, Spirulina platensis) }\end{array}$ & $\begin{array}{l}\text { GC (FID, MS) HPLC-QTOF- } \\
\text { MS }\end{array}$ & [43-51] \\
\hline Fruits (Italian walnut, Black mulberry, orange, blackthorn and rose fruits) & $\begin{array}{l}\text { GC-FID, ESR, spin-label } \\
\text { oximetry methods. }\end{array}$ & [52-56] \\
\hline
\end{tabular}


Table 2.- Lipids (except fatty acids) with potential nutraceutical activity found in different natural matrices, potential health effect and analytical techniques employed for their analysis.

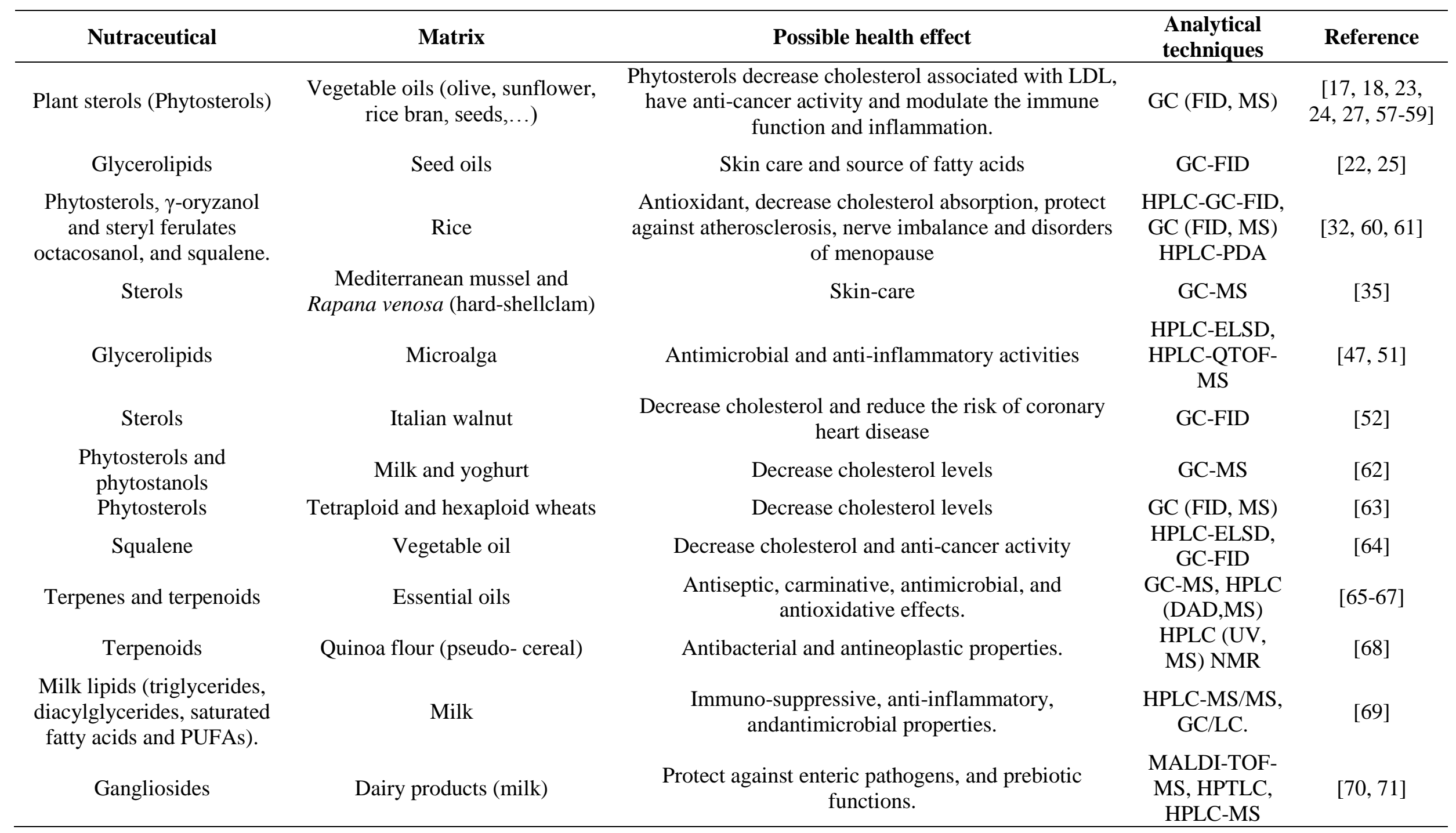


Table 3.- Carotenoid nutraceuticals found in different matrices, potential health effect and analytical techniques employed for their analysis.

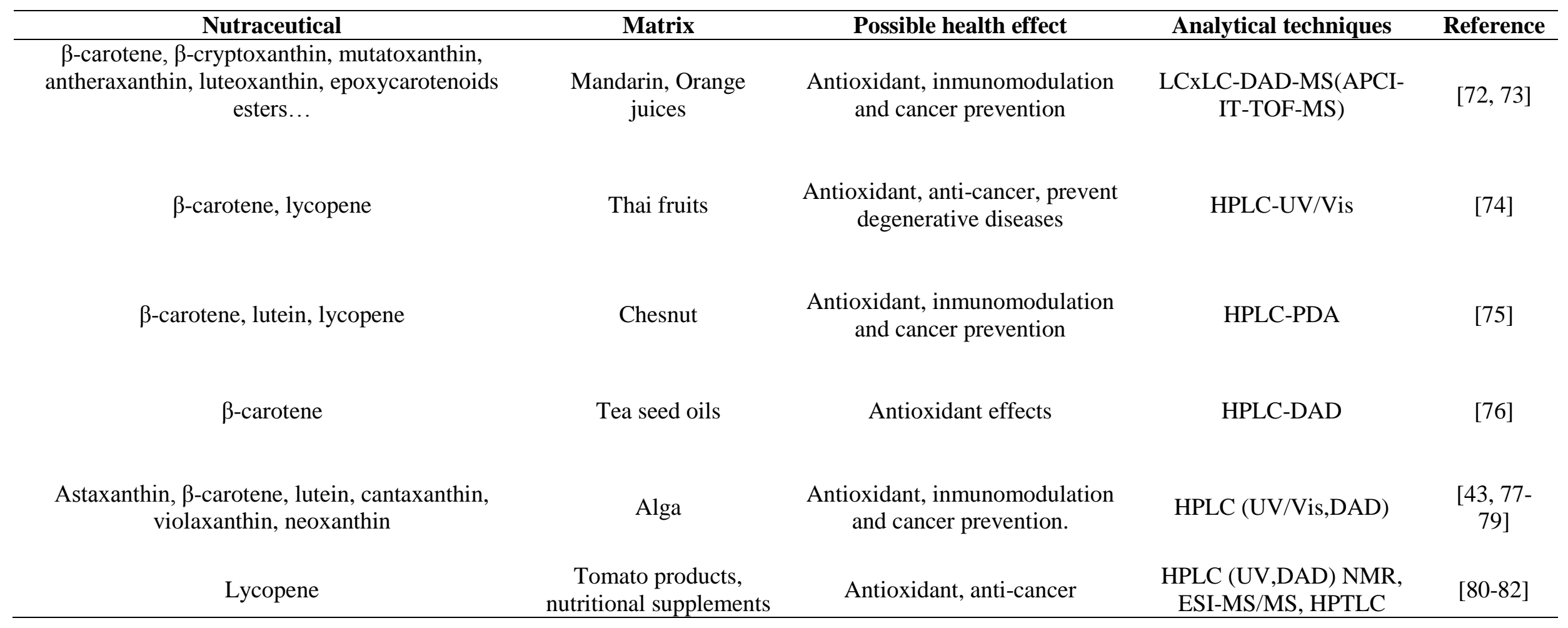


Table 4.- Vitamins found in different matrices, potential health effect and analytical techniques employed for their analysis.

\begin{tabular}{|c|c|c|c|c|}
\hline Nutraceutical & Matrix & Possible health effect & $\begin{array}{l}\text { Analytical } \\
\text { techniques }\end{array}$ & Reference \\
\hline Tocopherols (Vitamin E) & $\begin{array}{l}\text { Vegetable and } \\
\text { vegetable oils }\end{array}$ & $\begin{array}{l}\text { Antioxidant, antitumor, hypocholesterolemic } \\
\text { potential and for the treatment of } \\
\text { cardiovascular disease and angiogenic disorders }\end{array}$ & $\begin{array}{l}\text { HPLC (PDA,FLD, } \\
\text { VWD, MS), GC- } \\
\text { FID }\end{array}$ & $\begin{array}{l}{[17,18,23,24} \\
30,31,52,62,64 \\
87-89]\end{array}$ \\
\hline Tocopherols (Vitamin E) & Microalga & $\begin{array}{l}\text { Antioxidant and prevents degenerative } \\
\text { disorders }\end{array}$ & $\begin{array}{l}\text { HPLC (DAD, } \\
\text { FLD) }\end{array}$ & {$[44,49,90]$} \\
\hline Vitamin $\mathrm{B}_{1}$ and $\mathrm{B}_{2}$ & Mushrooms & Antioxidant & HPLC (DAD,FLD) & {$[91]$} \\
\hline $\begin{array}{l}\text { Water-soluble vitamins (B1, B2, two } \\
\text { B3 vitamers, B5, five B6 vitamers, B8, } \\
\text { B9, B12 and C). }\end{array}$ & $\begin{array}{l}\text { Maize flour, green } \\
\text { and golden kiwi and } \\
\text { tomato pulp. }\end{array}$ & Antioxidant and co-enzymes & HPLC-MS/MS & [92] \\
\hline Vitamins $\mathrm{B}_{2}, \mathrm{~B}_{3}$ and $\mathrm{B}_{6}$ & Energy drinks & Antioxidant and co-enzymes & $\begin{array}{l}\text { HPTLC, ESI } \\
\text { MS/MS }\end{array}$ & {$[86]$} \\
\hline Vitamin C (L-ascorbic acid) & Fruits & Antioxidant & $\begin{array}{l}\text { HPLC (UV/Vis, } \\
\text { VWD) }\end{array}$ & {$[89,93,94]$} \\
\hline L-ascorbic acid_dehydroascorbic acid) & Buckwheats & Antioxidant & HPLC-UV/Vis & {$[95]$} \\
\hline S-methyl-L-methionine (vitamin U) & Centella asiatica & Wound healing & HPLC-UV & {$[96]$} \\
\hline Fat and water soluble vitamins & $\begin{array}{l}\text { Beer and bioactive } \\
\text { drinks }\end{array}$ & Antioxidant and co-enzymes & HPLC-DAD & {$[97]$} \\
\hline
\end{tabular}


Table 5.- Proteins, peptides and aminoacids with potential nutraceutical activity found in different matrices, bioactivity and analytical techniques employed for their analysis.

\begin{tabular}{|c|c|c|c|c|}
\hline Nutraceutical & Matrix & Possible health effect & Analytical techniques & Reference \\
\hline $\begin{array}{l}\text { Milk proteins, peptides Lactoferrin } \\
\text { and immunoglobulin } \mathrm{G} \text {. }\end{array}$ & $\begin{array}{l}\text { Milk and derived } \\
\text { products }\end{array}$ & $\begin{array}{l}\text { Antihypertensive, antimicrobial, anti- } \\
\text { inflammatory and inmunostimulating } \\
\text { activities. Important source of amino acids }\end{array}$ & $\begin{array}{c}\text { HPLC-MS/MS, 2D-PAGE, } \\
\text { MALDI-TOFMS, Inmunosensors, } \\
\text { CE (UV, MS), }\end{array}$ & $\begin{array}{l}{[70,99-} \\
102]\end{array}$ \\
\hline Amino acids & $\begin{array}{l}\text { Sprouts, alga and } \\
\text { sport drinks and } \\
\text { tablets }\end{array}$ & $\begin{array}{l}\text { Eeffect on the nervous system, antioxidant, } \\
\text { anti-cancer and source of muscle energy }\end{array}$ & $\begin{array}{l}\text { HPLC (UV/Vis,MS) MEKC-LIF, } \\
\text { Microchip electrophoresis (MCE) }\end{array}$ & $\begin{array}{l}{[95,103-} \\
105]\end{array}$ \\
\hline Peptide & Fishes & $\begin{array}{l}\text { Antihypertensive, antioxidant and } \\
\text { anticoagulant activities }\end{array}$ & $\begin{array}{c}\text { HPLC-MS/MS,QTOFMS, GPC, } \\
\text { HPLC-FLD }\end{array}$ & [106-110] \\
\hline Type II collagen & Chick & $\begin{array}{c}\text { Can suppress Rheumatoid arthritis (RA) and } \\
\text { promote healthy joints. }\end{array}$ & SDS-PAGE, HPLC-UV/Vis, FTIR & {$[111]$} \\
\hline$\sim 35 \mathrm{kDa}$ antioxidant protein & Curry leaves & Antioxidant properties & SDS-PAGE, MALDI-TOF-MS & {$[112]$} \\
\hline Immunomodulatoryproteins & $\begin{array}{l}\text { Garlic (Allium } \\
\quad \text { sativum) }\end{array}$ & Immunomodulation activity & SDS-PAGE & {$[113]$} \\
\hline Total proteins & $\begin{array}{c}\text { Ganoderma } \\
\text { lucidum (fungi) }\end{array}$ & $\begin{array}{l}\text { Prevention and treatment of hypertension, } \\
\text { diabetes, hepatitis,cancers and AIDS }\end{array}$ & 2D-PAGE & {$[114]$} \\
\hline Lysozyme-derivedpeptides & Hen's egg & Antimicrobial activity & HPLC-MS/MS & {$[115]$} \\
\hline Cyclopeptides & Cow cockle seed & Estrogen like activity in vivo & HPLC-MS & [116] \\
\hline Phaseolamin & $\begin{array}{l}\text { Kidney bean } \\
\text { (Phaseolus vulg.) }\end{array}$ & $\begin{array}{l}\text { May reduce calorie absorbance, thereby } \\
\text { promoting weight loss. }\end{array}$ & HPAEC-PAD & {$[117]$} \\
\hline Selenopeptides & Nuts & Antioxidant, anti-cancer, anti-heart disease & nanoLC-Q/TOFMS/MS. ICP-MS & {$[118]$} \\
\hline
\end{tabular}


Table 6.- Glycosides with potential nutraceutical activity found in different matrices, bioactivity and analytical techniques employed for their analysis.

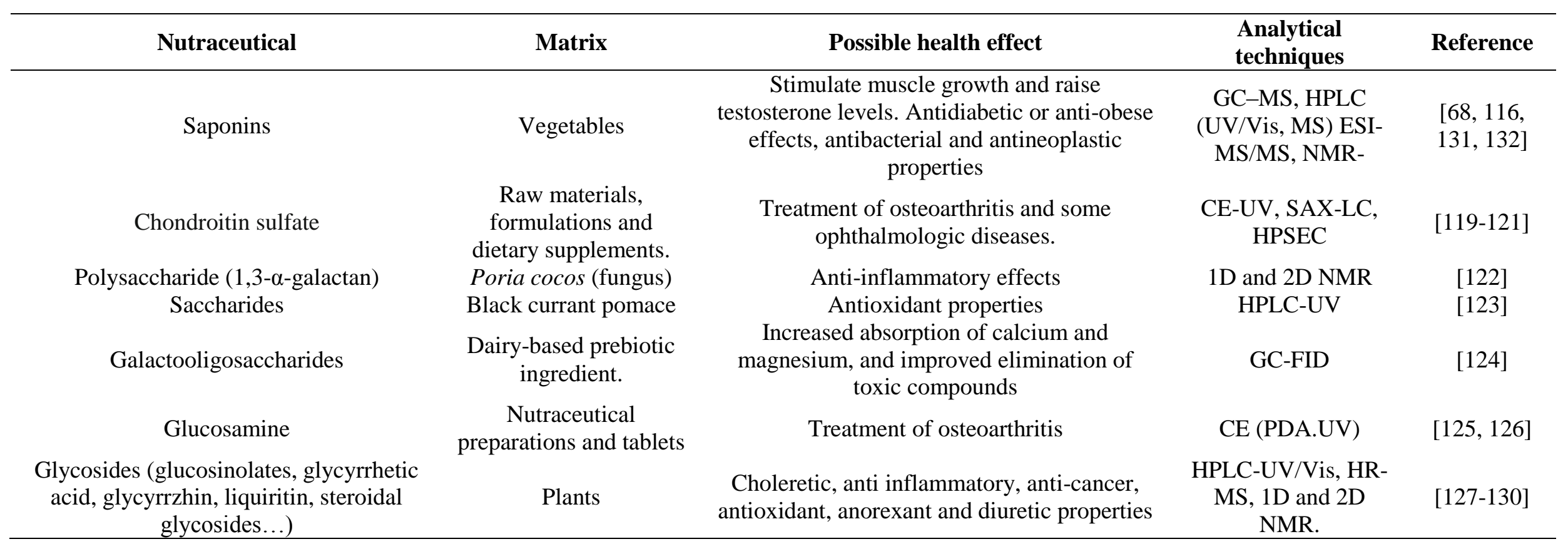


Table 7.- Phenolic compounds with potential nutraceutical activity found in different matrices, bioactivity and analytical techniques employed for their analysis.

\begin{tabular}{|c|c|c|c|c|}
\hline Nutraceutical & Matrix & Possible health effect & Analytical techniques & Reference \\
\hline Phenolic acids & Seed-oil & Antioxidant & HPLC-UV & [23] \\
\hline Phenolics & Fruits, Mushrooms, legumes & Antioxidant & HPLC-DAD & $\begin{array}{c}{[42,55,75,76} \\
89,97,141-156]\end{array}$ \\
\hline Phenolics & Fruits, Mushrooms, legumes & Antioxidant & HPLC-MS, HPLC-MS/MS & {$[157-166]$} \\
\hline Anthocyanins & Fruits, Nutraceutical Capsules & Antioxidant & HPLC-DAD & [167-173] \\
\hline Anthocyanins & Fruits, tubers & Antioxidant & HPLC-MS, HPLC-MS/MS & [174-177] \\
\hline Phenolics & Marula (Sclerocarrya birrea) & Antioxidants and Antiatherogenic & HPLC-DAD & [93] \\
\hline Catecholamines & Banana peel & Antioxidant & HPLC-DAD & [94] \\
\hline Rutin & Buckwheats & Antioxidant & HPLC-DAD & [95] \\
\hline Flavone isomers & lemon juice & Antioxidant & HPLC-DAD-ESI-MS/MS & [178] \\
\hline Phenolics & Potatoe & Antioxidant & HPLC-DAD, NMR & [179] \\
\hline Phenolic acids & Cooked meat & Antioxidant & HPLC-DAD & [180] \\
\hline Flavonol & Bean & Antioxidant & $\begin{array}{c}\text { HPLC-DAD, prepHPLC, } \\
\text { NMR }\end{array}$ & [181] \\
\hline Phenolics & Moscatel sweet wines & Antioxidant & HPLC-DAD, HPLC-FD & [182] \\
\hline Phenolics & Carex distachya roots & Antioxidant & HPLC-DAD-MS, NMR & [183] \\
\hline Curcuminoids & Curcuma longa & Antioxidant & HPLC HPTLC & [184] \\
\hline Lignans & Flaxseed & Antioxidant & PLE HPLC-UV & [185] \\
\hline $\begin{array}{l}\text { Phenolic acids, } \\
\text { proanthocyanidins, and lignans }\end{array}$ & Triticale & Antioxidant & HPLC-DAD & [186] \\
\hline Flavonoids & Ulmus davidiana & Antioxidant & HPLC-DAD & [187] \\
\hline Resveratrol & Grape canes & Antioxidant & HPLC-DAD & [188] \\
\hline Phenolic acids and flavonoids & $\begin{array}{l}\text { Glycin tomentella Hayata } \\
\text { (Leguminosae family) }\end{array}$ & Antioxidant & HPLC-DAD & [189] \\
\hline Phenolic acids & Mulberry & Antioxidant & HPLC-DAD & [190] \\
\hline Chicoric acid & seagrass Syringodium filiforme & Antioxidant & HPLC-DAD-MS & [191] \\
\hline
\end{tabular}


Resveratrol

Flavonoids

Phenolic acids

Silymarin

Flavonoid aglycones

Flavonoids

Demethyloleuropein

Alkil phenols

Flavonoids

Phenolic acids, isoflavones

Phenolics

Phenolic acids

Catechins and condensed tannins

Phenolic acids

Phenolics

Phenolics

Phenolics

Flavonoids and phenolic acids

Resveratrol

Phenolics

Lignans

Prunate

Polymethoxilated Flavones

$$
\text { Carnosic }
$$

Licochalcone A

Phlorotannins

Phytoestrogens

Flavonol glycosides
Nutritional suplements

Wild rice

Rice

Milk thistle

black currant

Cranberry

Olive fruit

Anacardum

Hypericum perforatum

Black Soybeans

Pepper

Malt

Green Tea

Mangosteen

Bergenia ciliata

Vanilla planifolia

Grape

Chinese herbal tea

Nutraceutical capsules

Grape skin

Myristica fragrans (nutmeg)

\section{Prunus}

Orange Oil

Rosemary

Glycyrrhiza uralensis

Alga (Ishige okamurae)

Dietary supplements

Ginkgo biloba
Antioxidant

Antioxidant

Antioxidant

Antioxidant

Antioxidant

Antioxidant

Antioxidant

Antioxidant

Antioxidant

Antioxidant

Antioxidant

Antioxidant

Antioxidant

Antioxidant

Antioxidant

Antioxidant

Antioxidant

Antioxidant

Prevention of atherosclerosis

Antioxidant

Anticariogenic

Anticarcinogenic

Antioxidant

Antioxidant

Lipase inhibition

Cholinesterase inhibition

Estrogenic activity

Memory enhancing

$\begin{array}{cc}\text { HPLC-UV } & {[192]} \\ \text { HPLC-DAD-MS/MS } & {[193]} \\ \text { HPLC-DAD-MS/MS } & {[194]} \\ \text { HPLC-UV } & {[195]} \\ \text { HPLC-MS/MS } & {[196]} \\ \text { HPLC-DAD-MS, NMR } & {[197]} \\ \text { HPLC-DAD-MS } & {[198]} \\ \text { HPLC-MS, GC-MS, NMR } & {[199]} \\ \text { HSCCC, prep-HPLC, NMR } & {[200]} \\ \text { HPLC-DAD } & {[201]} \\ \text { GC, TLC, Voltametry } & {[202]} \\ \text { GC-MS } & {[203]} \\ \text { GC-MS } & {[204]} \\ \text { GC-FID GC-MS } & {[205]} \\ \text { HPTLC } & {[206]} \\ \text { HPTLC PLE MAE } & {[207]} \\ \text { CE-UV } & {[208]} \\ \text { CZE-AD } & {[209]} \\ \text { CE } & {[210]} \\ \text { CE-Fluo CE-DAD } & {[211]} \\ \text { NMR, MS, GPC } & {[212]} \\ \text { MS, NMR } & {[213]} \\ \text { FTIR } & {[214]} \\ \text { NMR FTIR } & {[215]} \\ \text { NMR MS } & {[216]} \\ \text { NMR } & {[217]} \\ \text { HPLC-UV } & {[218]} \\ \text { HPLC-UV } & {[219]} \\ & \end{array}$


Isoflavones

Isoflavones

Phenolics

Flavonoids

Resveratrol Oligomers and

Flavonoids

Phenolic acids

O-glucoside phenolic compounds

Isoflavones

Isoflavones

Isoflavones
Soy milk

Soy supplements

Tamarix gallica

Citrus peel

Carex folliculata Seeds

Infant cereals

Olive by-products

Soybean seeds

Red clover

Nutritional supplements
Estrogenic activity

Antimenopausial sympthoms

Antioxidant and antimicrobial

Antiinflammatory, anticarcinogenic and antiatherogenic

Antioxidant, cytotoxicity and antibacterial

Antioxidant \& aroma

Antioxidant, maturity indicators

Antimenopausial sympthoms

Antifungal activity

Estrogenic activity
HPLC-DAD

HPLC-DAD

HPLC-DAD

HPLC-ESI-MS NMR

HPLC-DAD, NMR

HPLC-DAD-MS/MS

HPLC-DAD-MS/MS

HPLC-UV

HPLC-DAD

[228]

HPLC-DAD 
Table 8.- Other potential nutraceuticals found in different natural matrices, their possible health effect and the analytical techniques employed for their analysis.

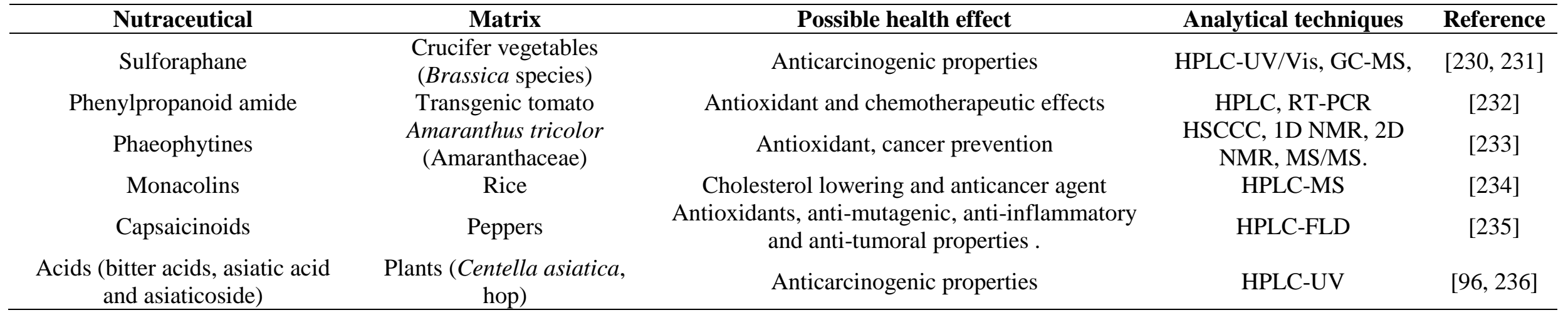


Click here to download high resolution image

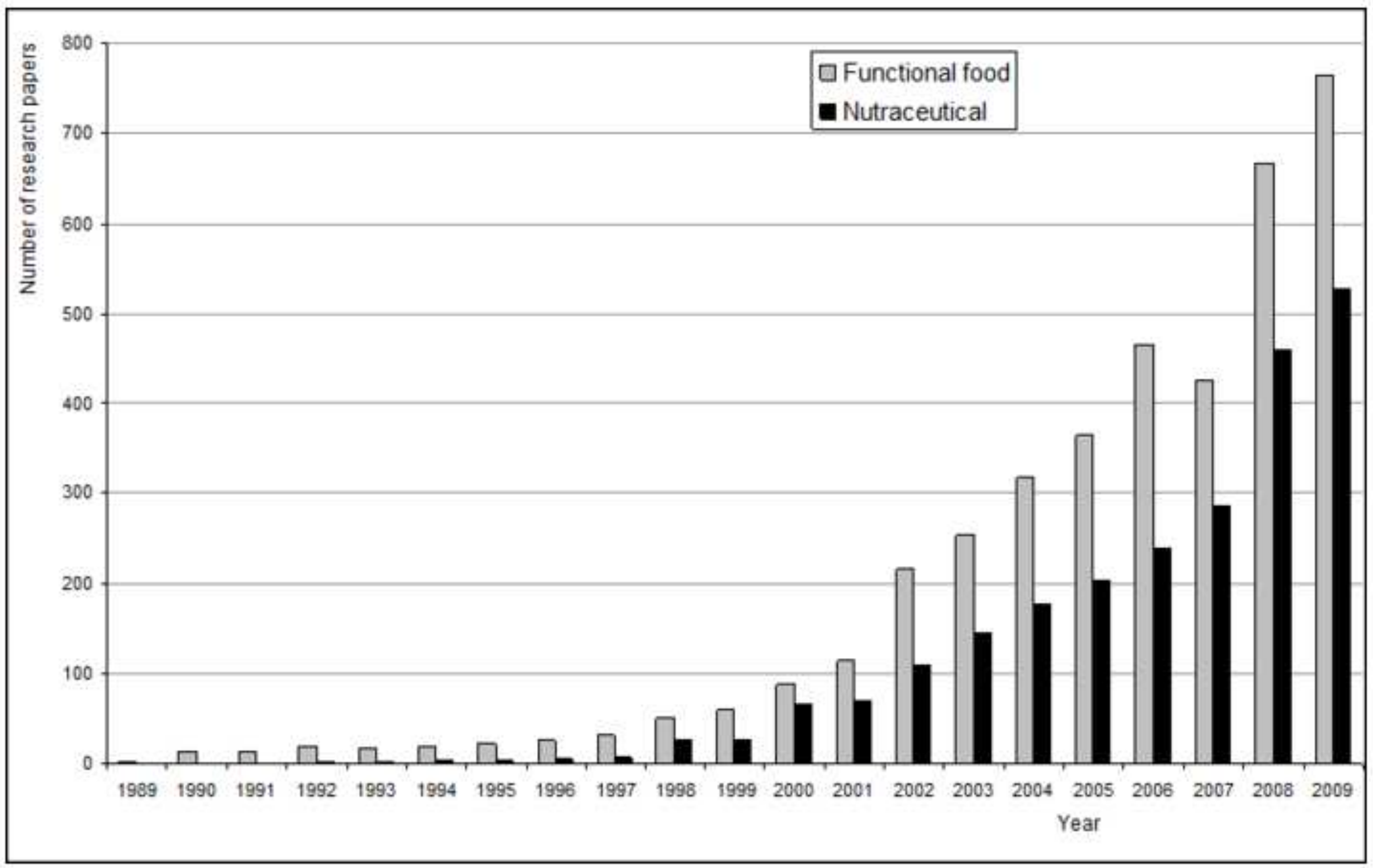


Click here to download high resolution image
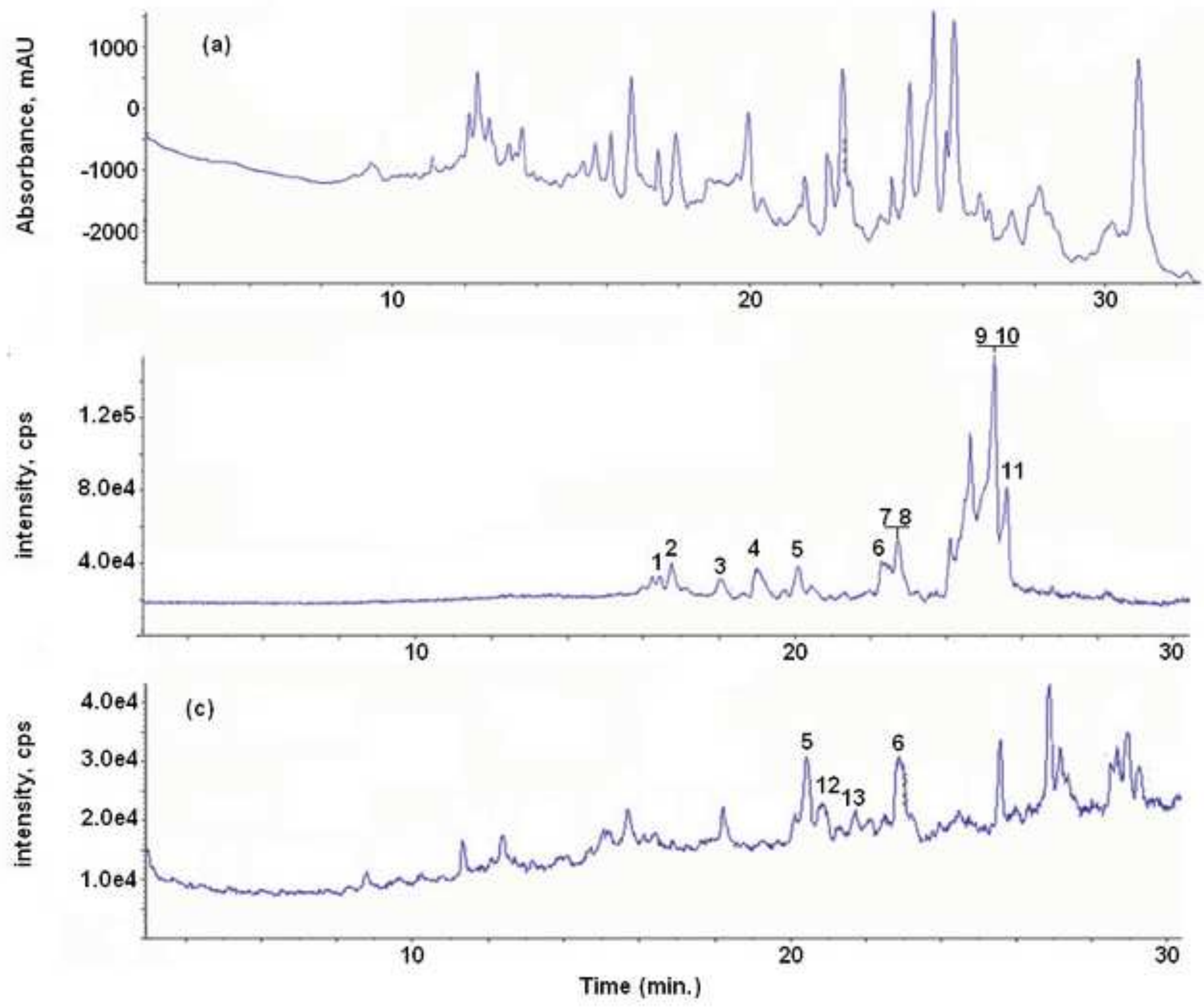

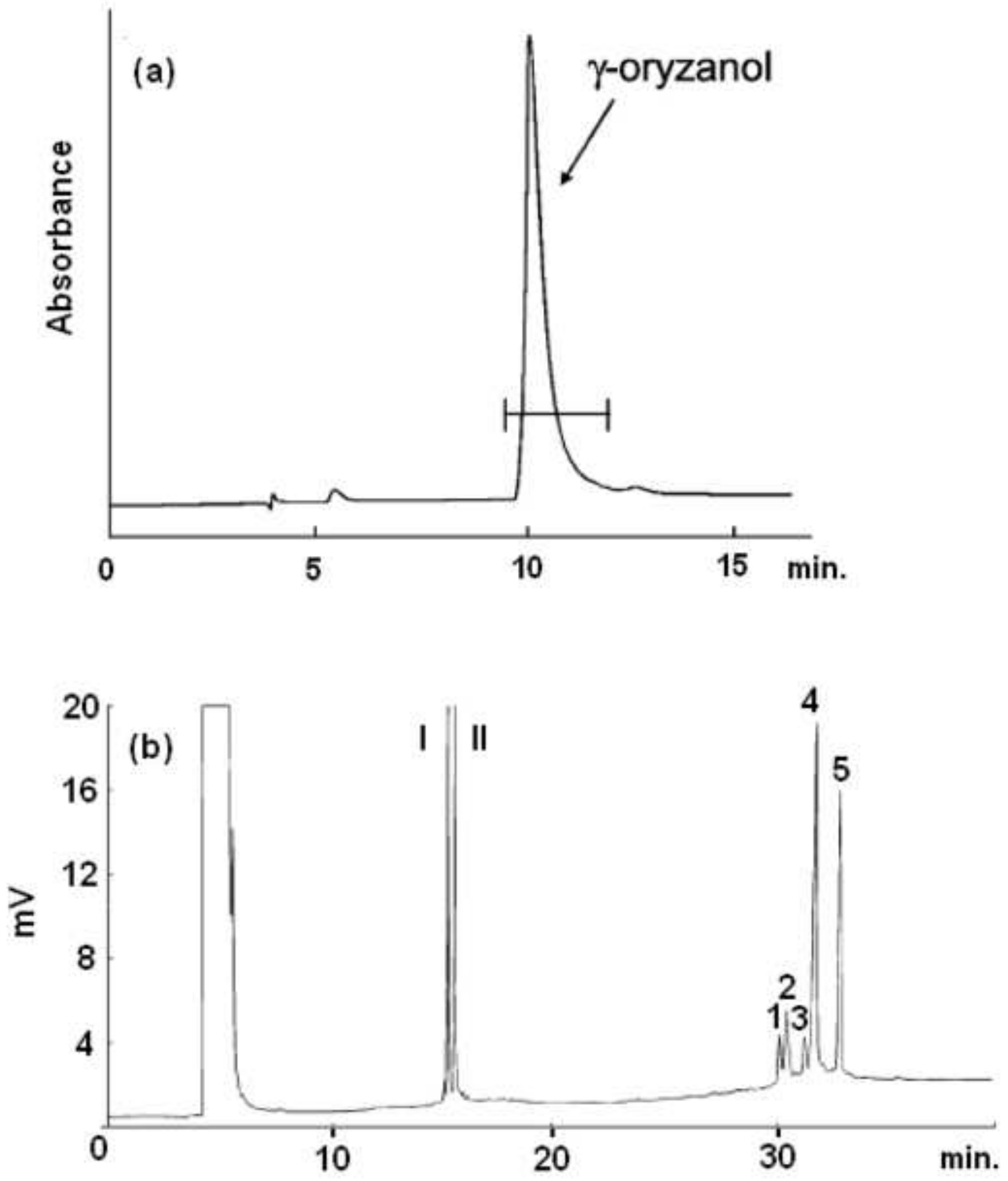
Click here to download high resolution image

(a)

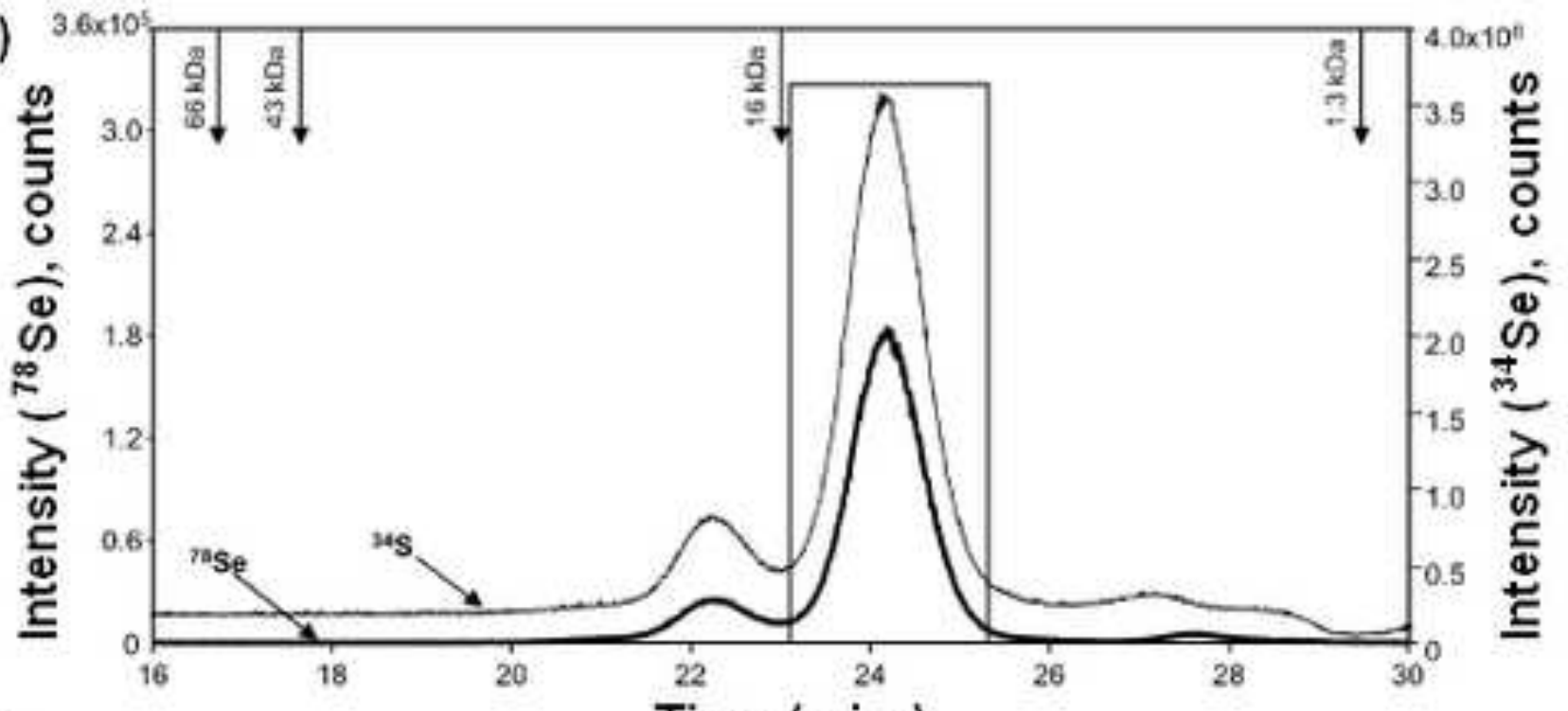

(b)

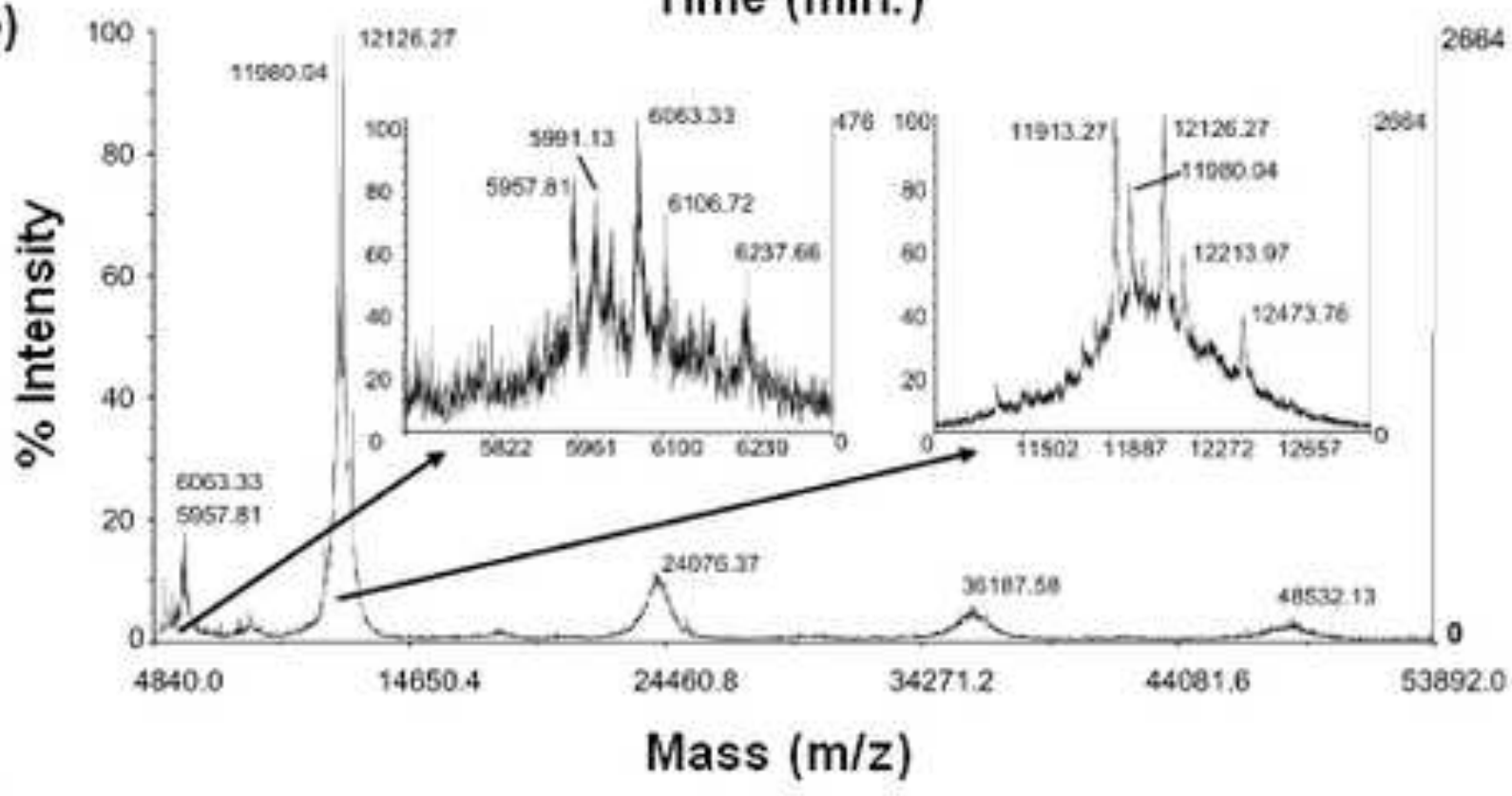

(c)

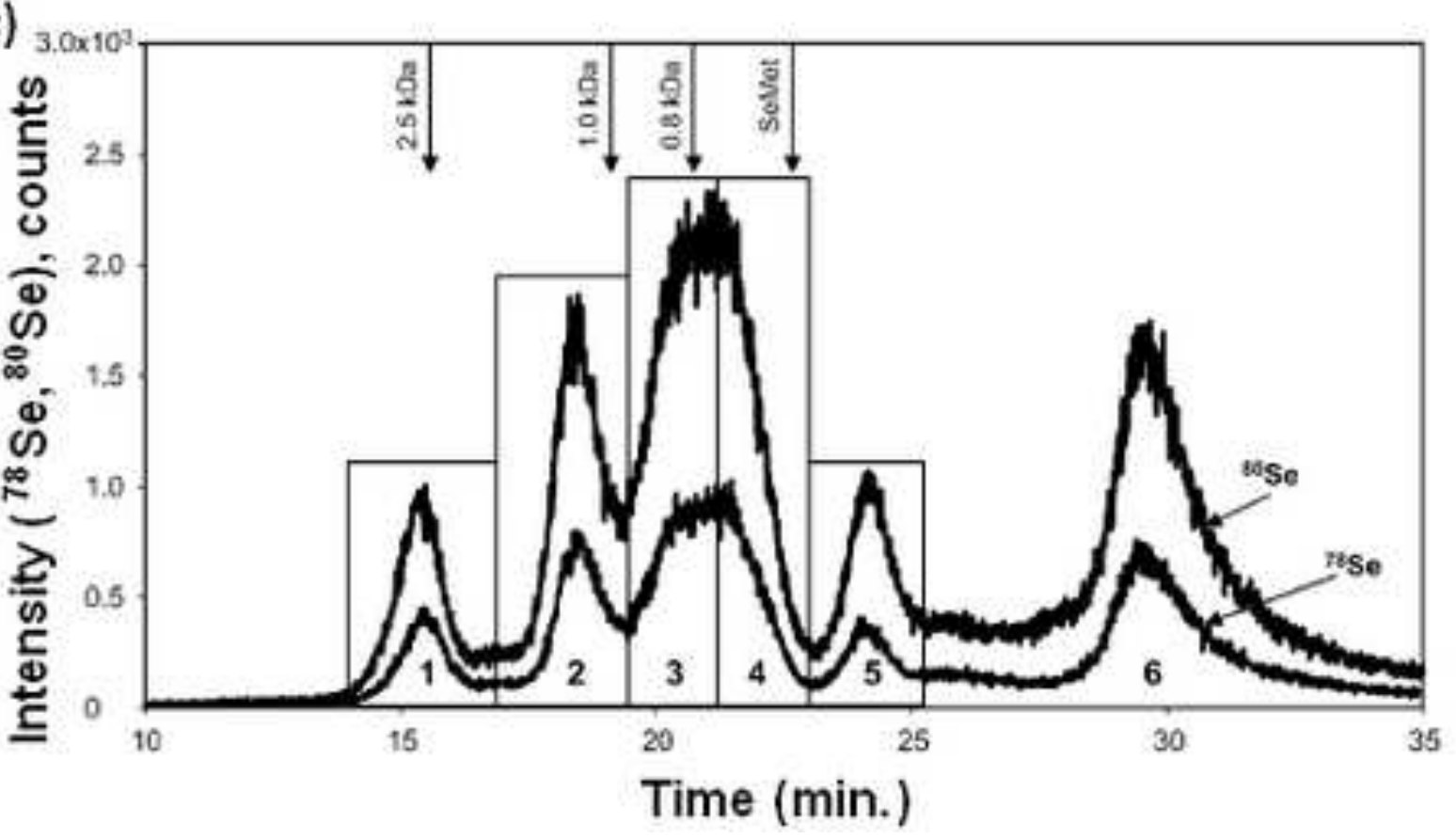


Click here to download high resolution image

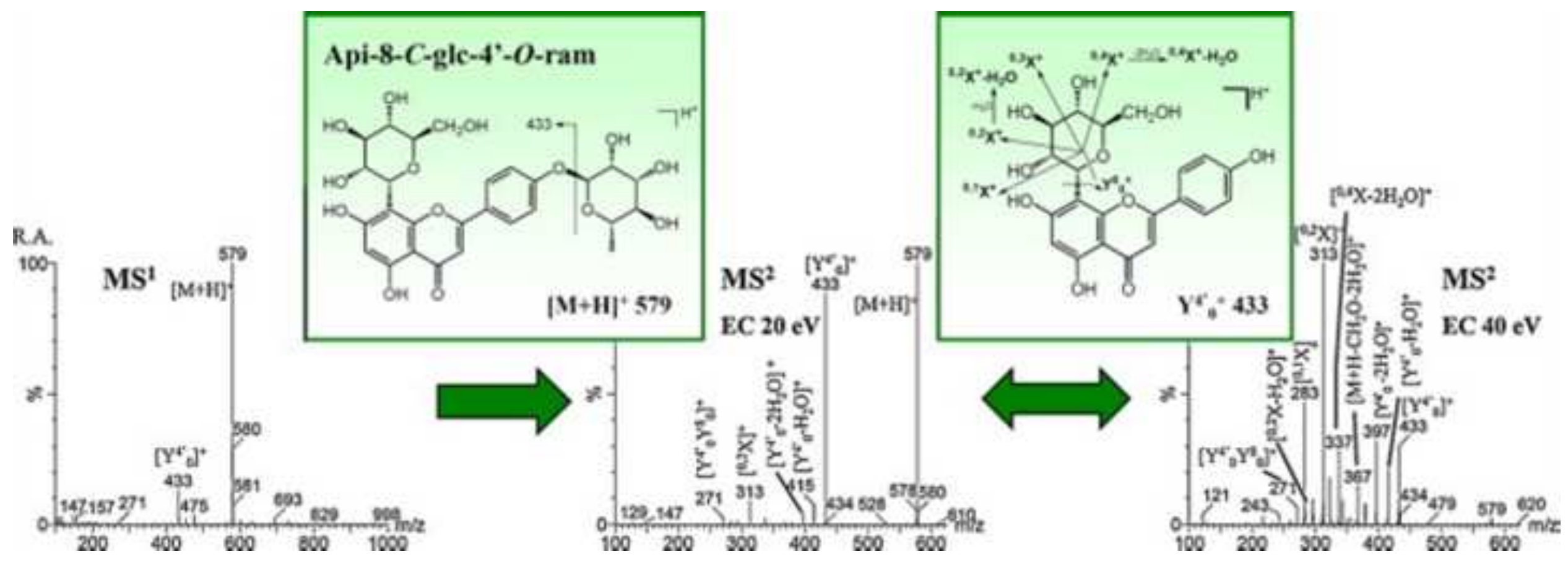



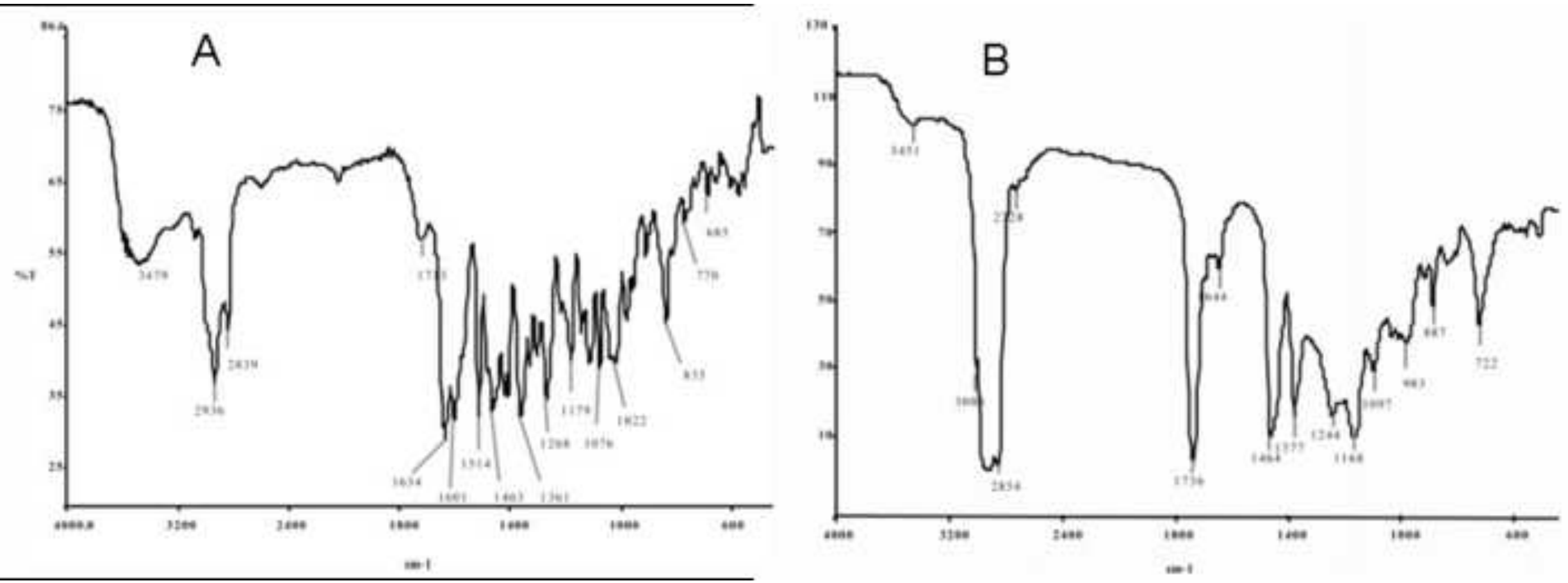